

\title{
'Sabia que Estaria Aqui': Relatos sobre os Processos Criativos do Projeto 'Uma Cidade pelas Margens'
}

\author{
Caracas y Mérida, Venezuela: Colonialismo Territorial y Género en la película \\ Azul y no tan Rosa
}

'I Knew I Would be Here': Reports on the Creative Processes of the Project 'A
City by the Margins'

Resumo

Este texto relata o processo de criação e desenvolvimento do projeto "Uma Cidade pelas Margens" voltado à história e memória da população LGBTT em Porto Alegre. As atividades foram realizadas no Museu de Porto Alegre Joaquim Felizardo entre os meses de agosto e dezembro de 2016 e consistiram na elaboração de uma exposição de curta duração - que fícou em cartaz entre novembro e dezembro de 2016; duas mesas redondas e um piquenique cultural temático.

Palavras-Chave: Margem; LGBTT; Exposição; Memória.

\section{Resumen}

Este texto relata el proceso de creación y desarrollo del proyecto "Una Ciudad en Margens" volvió a la historia y la memoria de la población LGBTT en Porto Alegre. Como se realizaron las obras no de Museu de Porto Alegre Joaquim Felizardo entre los meses de agosto y diciembre de 2016 y consistiram en la elaboración de una exposición de corto plazo - que quedó en la carta entre noviembre y diciembre de 2016; Dos mesas redondas y un piquenique cultural temático.

Palabras-Clave: Cine y Ciudad; Espacios; Género y Sexualidad; Colonialismo Territorial.

\section{Abstract}

This text describes the process of creation and development of the project "A City by the Margin" focused on the history and memory of the LGBTT population in Porto Alegre. The activities were held at the Porto Alegre Museum Joaquim Felizardo between August and December 2016 and consisted in the elaboration of a short exhibition - which was shown between November and December 2016; two round tables and a themed cultural picnic.

Keywords: City; Margin, LGBTT; Exhibition; Memory. 
Margem. [do lat. Margine]. S. f. 1. Parte em branco ao redor de uma folha manuscrita ou impressa, a qual parte pode às vezes conter ilustrações e notas. 2. Linha ou faixa que limita ou circunda alguma coisa; borda, beira, orla. 3. O terreno que ladeia um curso de água ou que circunda um lago; beira, orla. [...] 4. Fig. Espaço livre, de tempo ou lugar. 5. Fig. Ensejo, ocasião, oportunidade. [...] à margem. De parte; de lado: pôr à margem, ficar à margem. Dar margem a. Dar ocasião, proporcionar ensejo a.

[Novo Dicionário Aurélio, 1993]

Estou sentada sozinha na sala de exposição assistindo uma das entrevistas que não havia visto até o final. Entra um senhor de camiseta polo e calça jeans, pasta de couro na mão. Coloca os óculos e vai olhando tudo. Na saída me diz com uma risadinha: - Sabia que estaria aqui! Era a Brigitte, de meia arrastão, colant e salto alto numa foto com Marcelly Malta. Tinha ido à exposição pra se ver.

[Anotação particular da autora, 2016]

\section{O Início do Percurso}

Estar à margem e dar margem à. Foi a partir dessas duas acepções possíveis para o vocábulo margem que teve início o processo reflexivo para o desenvolvimento do projeto "Uma Cidade pelas Margens", voltado à história e memória da comunidade LGBTT em Porto Alegre. ${ }^{1} \mathrm{O}$ trabalho foi o resultado de uma ação colaborativa realizada entre diferentes instituições e grupos e teve como principal objetivo levar a pauta das diversidades de identidades, expressões de gênero e orientações sexuais para o Museu de Porto Alegre Joaquim Felizardo 2.

História e memória da população LGBTT ainda são severamente negligenciadas pelas instituições museais, a despeito dos movimentos sociais engajados na luta pela visibilidade LGBTT. Esse silêncio, produto escamoteado de condutas fóbicas ${ }^{3}$ em relação às pessoas que não se identificam com padrões heteronormativos culturalmente impostos, é apontado em diferentes pesquisas.

Em artigo de 2014, Jean Baptista e Tony Boita revisitaram iniciativas nacionais e internacionais que buscaram relacionar Museologia e a temática LGBTT, indicando a produção incipiente tanto nos museus quanto no meio

1 Sigla para gueis (forma à moda brasileira para se referir aos homossexuais, utilizada pelo jornal Lampião da Esquina e pelo Nuances), lésbicas, bissexuais, travestis, pessoas transexuais e transgênero.

2 O Museu de Porto Alegre Joaquim Felizardo está subordinado à Coordenação da Memória Cultural, pertencente à Secretaria da Cultura da Prefeitura Municipal de Porto Alegre. 
acadêmico. Renato Pinto (2012), da mesma forma, indicou a relutância de estudiosos da cultural material em abordar os temas de gênero e diversidade sexual. A ausência (e/ou invisibilidade) do legado material de pessoas LGBTT em museus é notória, como bem apontou Flávio Amaral (2014), denotando "violência ao eliminar dessa 'curadoria do mundo' as memórias das pessoas e das vidas dessas pessoas [LGBTT]" (AMARAL, 2014, p. 239).

Esse silenciamento reflete diretamente na ausência de acervos claramente associados ao universo LGBTT. Conforme alerta Flávio Amaral (2014), ainda é reduzida a expectativa de que coleções e acervos dessa população sejam objeto de interesse em uma realidade onde direitos básicos ainda são motivo de conflito e negociação. Mais que isso, indaga o autor, qual afinal a diferença entre a cultura material de heterossexuais e de pessoas de orientações sexuais e identidades de gênero diversas desta? Em parte considerável dos objetos, nenhuma. A diferença estaria, justamente, em registrar memórias e usos associados a determinado artefato, de modo a evitar que a relação entre a cultural material e o universo LGBTT seja "escamoteada, esquecida ou ignorada" (AMARAL, 2014, p. 247).

Na contramão desse cenário, em agosto de 2016 teve início a parceria entre o Museu e o Nuances - Grupo pela Livre Expressão Sexual com o objetivo de elaborar um projeto que trouxesse diferentes trajetórias da militância e de pessoas LGBTT para o Museu. Pouco tempo antes, em 11 de junho do mesmo ano, um atentado realizado na boate Pulse, em Orlando, nos Estados Unidos, havia aumentado a lista dos crimes motivados pela LGBTfobia, com um total de 49 vítimas fatais e 53 feridos $\mathrm{Na}$ época, em Porto Alegre, o Coletivo de Organização da $20^{\mathrm{a}}$ Parada Livre ${ }^{4}$ (COPL) chamou um ato público ${ }^{5}$, no dia do

3 "O preconceito mata" - afirma Nardi (2013, p. 29), quando explica que a diminuição da autoestima, o aumento na incidência de suicídios e depressão, o comportamento de risco, o uso abusivo de álcool e outras drogas estão associados ao preconceito e ações discriminatórias. Existem outros termos utilizados para designar formas análogas e específicas de discriminação: a putafobia, referente às pessoas que fazem prostituição, profissionais do sexo e trabalhadores sexuais; travestifobia e transfobia, que correspondem, respectivamente, à população de travestis e, pessoas transexuais e transgêneros; lesbofobia, referente à população de mulheres lésbicas e; a bissexualfobia, correspondente às pessoas bissexuais (RIOS, 2007). Para compreender esses conceitos, faz-se necessário entender essas "fobias" como um preconceito que se origina através de uma construção social e, não por comportamentos patológicos, visto que estão conceitualmente equivocados, apesar de assimilados ao senso comum (NARDI, 2013). Não há nada de patológico na prática da homolesbotransfobia, assim como não há nada de patológico no racismo, anti-semitismo ou sexismo; são práticas que deve-se analisar sob o prisma dos direitos humanos, no âmbito da violação desses direitos (BARNART, 2014).

4 O Coletivo de Organização da Parada Livre de Porto Alegre é formado por diversas instituições da sociedade civil, grupos e cidadãos, ligados à partidos políticos ou não, que tenham interesse em participar do processo de organização desse ato público anual. De livre adesão e autônomo, organiza-se de maneira horizontal e sem hierarquias, com tomadas de decisão de forma democrática por consenso ou votação. Esse grupo não tem uma constituição definida, tendo sua formação feita de forma sazonal, sendo que de um ano para o outro novos participantes podem se agregar ao processo, assim como outros participantes podem abandonálo livremente. Possui como objetivo principal a organização da Parada Livre, que inclui definição da temática, captação de recursos públicos e/ou privados para realização do evento, questões de ordem burocrática, articulações diversas, entre outros. Também pode propor e criar outras iniciativas durante esse processo, por exemplo: atos públicos, seminários, exposições, etc. Essas iniciativas podem ser propostas por qualquer participante, seja indivíduo, grupo ou instituição. 
Orgulho LGBTT, realizado na Esquina Democrática, no centro da capital gaúcha. A manifestação contou com a presença de diversos representantes de movimentos sociais, coletivos e pessoas que se agregaram à movimentação, atendendo ao chamado das entidades organizadoras do evento. Durante o ato, foi distribuído o panfleto DIA DO ORGULHO LGBTT - SE ORGULHAR É RESISTIR, com um convite à reflexão sobre a realidade local: no Brasil também existe um massacre de pessoas LGBTT todos os anos.

Segundo os dados do Grupo Gay da Bahia (GGB), no ano de 2015 o número de vítimas fatais de LGBTfobia foi de 318 pessoas, quase $650 \%$ maior do que em Orlando. Em declaração ao jornal Sul21, Marcelly Malta ${ }^{6}$ enfatizou a repercussão negativa da tragédia ocorrida nos Estados Unidos e mencionou a realidade brasileira, em especial a situação de travestis e pessoas transexuais que são o segmento mais vulnerável da população $\mathrm{LGBT}^{7}$, vítimas do preconceito, da discriminação e da violência letal: "O que aconteceu em Orlando choca muito, mas no Brasil já temos 62 travestis assassinadas em 2016" - declarou a militante. ${ }^{8}$ Evidentemente, a intenção não foi comparar os eventos para diminuir o ocorrido, mas trazer para reflexão a realidade em escala nacional. $\mathrm{O}$ ato também propôs uma intervenção urbana, os participantes deitaram no chão e tiveram o contorno de seus corpos marcados em giz, que simbolicamente representou às vítimas da LGBTfobia em Orlando, no Brasil e no mundo. De acordo com o manifesto do COPL:

O massacre de Orlando é consequência do discurso homofóbico, do [discurso] fundamentalista religioso, das políticas públicas excludentes, da ausência do debate sobre gênero das escolas, das piadas transfóbicas de bar e a violência física e psicológica que cada

\begin{abstract}
5 Para saber mais consulte o link: <http://www.sul21.com.br/jornal/dia-do-orgulho-LGBTTadverte-para-violencia-e-retrocesso-conservador/> Acesso em 20 de fev. de 2017.

6 Marcelly Malta também é Vice-Presidenta da RedeTrans Brasil - Rede de Pessoas Trans do Brasil, instituição que possui uma iniciativa de sistematização dos casos de violação de direitos humanos e violências contra população de travestis e pessoas transexuais no país, que iniciou através de uma iniciativa da professora de geografia e militante Sayonara Nogueira Secretária de Comunicação da Rede Trans Brasil, a partir da criação de um projeto chamado "Cartografia da Resistência", que utilizou o método da cartografia social em sala de aula com base em dados de violência letal contra pessoas LGBTTs no Brasil. A partir disso, Sayonara deu continuidade ao trabalho e criou um blog para divulgar os casos de violência contra população de travestis e pessoas trans. Esse trabalho foi incorporado à agenda da Rede Trans Brasil, que posteriormente criou um site para dar mais visibilidade ao projeto. Logo em seguida, essa iniciativa proporcionou uma parceria com a organização não-governamental alemã Transgender Europe (TGEU) que também realiza o monitoramento dos casos de pessoas trans assassinadas, porém em escala global. O primeiro produto da parceria entre a Rede Trans e a TGEU foi o "Dossiê: A Geografia dos Corpos das Pessoas Trans" (informações de acesso nas referências desse texto), lançado no Rio de Janeiro em 29 de janeiro de 2017 - Dia Internacional da Visibilidade Trans.
\end{abstract}

7 "As pessoas trans compõem um grupo muito vitimizado no país. O risco de uma pessoa travesti, transexual ou transgênero ser assassinada é 14 vezes maior que o de um homem cis gay, e a chance dessa morte ser violenta é 9 vezes maior. Segundo agências internacionais, quase metade dos homicídios contra pessoas trans do mundo ocorre no Brasil." (NOGUEIRA; AQUINO; CABRAL, 2017, p.4).

8 Disponível em:<http://www.sul21.com.br/jornal/dia-do-orgulho-LGBTT-adverte-paraviolencia-e-retrocesso-conservador/> Acesso em 20 de fev. de 2017. 
criança LGBTT sofre na família e espaços públicos. O atentado à boate Pulse, em Orlando, é resultado de uma sociedade violenta e excludente. (COPL, 2016, s. p.)

A diversidade de expressões sexuais exposta nas paradas do orgulho LGBTT provoca reação dos setores mais conservadores da sociedade através de um discurso que associa as expressões sexuais dissidentes da heterossexualidade ao abuso sexual, à pedofilia, à imoralidade, ao pecado, ao crime e à doença, entre outros. Representantes de partidos conservadores de direita, ligados às instituições religiosas e militares, têm disseminado esses discursos de ódio nas arenas políticas ${ }^{9}$ e nas mídias. "Podemos dizer que as agressões que gueis, lésbicas e travestis vêm sofrendo em pleno espaço público, [...] encontram justificativas nesses discursos de ódio" (GOLIN, 2013, s.p.) que são proferidos livremente, inclusive em espaços públicos por meio de pronunciamentos oficiais de parlamentares e, também, enunciados com naturalidade nas instâncias de tomada de decisão do Estado Brasileiro (BARNART, 2014, p. 19).

$\mathrm{Na}$ época do atentado em Orlando, o Museu de Porto Alegre Joaquim Felizardo também posicionou-se lamentando o ocorrido, postando em sua página no Facebook uma imagem do acervo de sua Fototeca produzida por Virgílio Calegari no final do século XIX, na qual duas mulheres aparecem se beijando (Figura 1).

Figura 1 - Print da postagem na página do Facebook do Museu de Porto Alegre Joaquim Felizardo. 2016. Acervo dos autores.
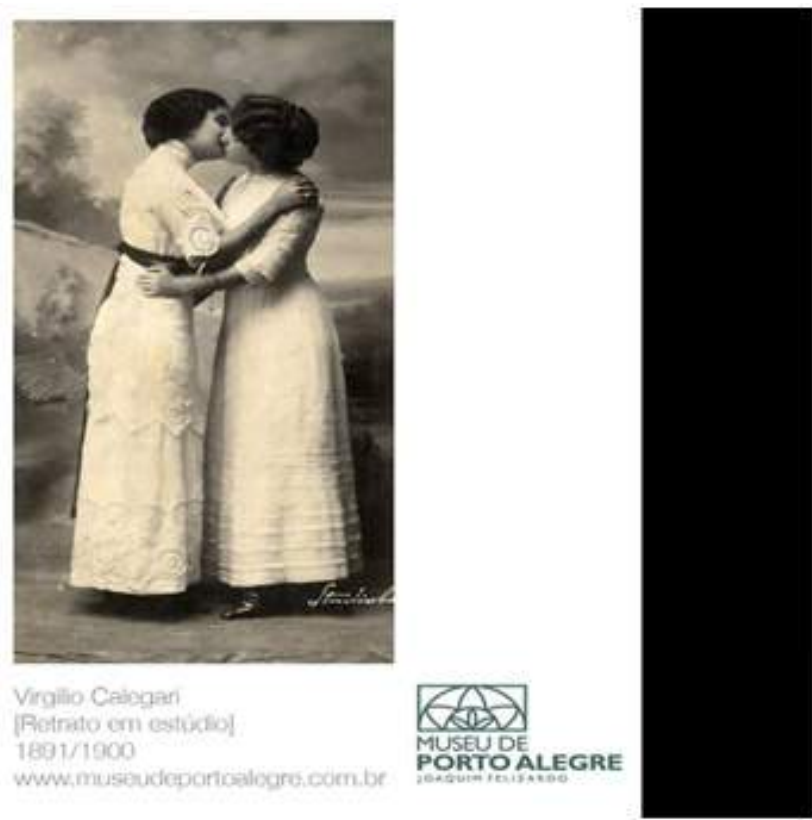

Kans Museu de Porto Alegre Joaquim Felizardo Pelizaracaitios 13 de juine de 2016 i Eotads

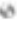

Nosso post da Fototeca de hoje presta uma homenagem a toda a populaça LGBT e posiciona-se contra todo e qualquer tipo de vioulencia nomotóbica:

O retrato, provavementente do final do século XIX integra nosso acervo e é assinado por Virgillo Calegari Nå existem intormaçరes precisas sobre as retratadas, tampouco sobre seu contexto de. produçăo. Muitos envergam nelas duas amigas ou iml's Mas por que năo poderia ser um belio entre amantes?

Nós, equipe do Museu de Porto Alegre Joaquin Fetizardo, somos a favor da diversidade. Que o respeito prevaleça sobre o preconcelto, a discriminaçào e a exclusăo

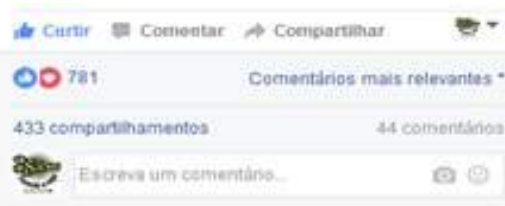

9 "Se a política envolve a tomada de decisões coletivamente impositivas, e portanto incorpora fatalmente disputas públicas em torno dessas decisões, a expressão "arena política" refere-se à delimitação do campo, do ambiente, da cena onde se travam essas disputas. As características da arena política determinarão, em grande parte, a dinâmica da vida política, conforme as instituições decisórias vigentes, a configuração organizacional dos grupos, os valores e/ou prioridades estratégicas dos contendores" (REIS, 2013, s. p.). 
A reação do público a essa postagem foi incomparável a outras até então realizadas pela instituição. O número de compartilhamentos e a intensidade dos comentários ${ }^{10}$ indicava que, sem dúvida, esse era um tema que deveria ser discutido no espaço do Museu. Mas como estruturar essa proposta?

O primeiro passo dado foi entrar em contato com o Nuances - Grupo pela Livre Expressão Sexual, grupo que se dedica, desde a década de 1990, à militância e à reflexão sobre a pauta LGBTT em Porto Alegre. Logo em seguida outros grupos integraram-se ao processo criativo, como a Liga Brasileira de Lésbicas do Rio Grande do Sul (LBL-RS) e a Igualdade Associação de Travestis e Transexuais do Rio Grande do Sul, além do Memorial do Tribunal Federal do Rio Grande do Sul, do Curso de Graduação em Museologia, do Laboratório de Políticas Públicas Ações Coletivas e Saúde (LAPPACS) e do Programa de Pós-Graduação em História (PPGHIST), sendo os três últimos vinculados à Universidade Federal do Rio Grande do Sul (UFRGS).

O tema da $20^{a}$ edição da Parada Livre, realizada em 2016, já apontava para importância em discutir as territorialidades das pessoas LGBTT com a temática "PARADA LIVRE 20 ANOS - ROMPENDO NORMAS, CONQUISTANDO TERRITÓRIOS". A exposição, não por acaso, foi inaugurada uma semana após shows, discursos e livre expressão LGBTT terem ocupado um espaço público de referência da cidade: o Parque Farroupilha, ou Parque da Redenção, ou "Rendereca" para as "bichas"."1 Foram tempos, também, de ocupar o espaço do Museu, territorializando a cultura, a sociabilidade e a memória LGBTT.

10 Inicialmente, foram postados três comentários preconceituosos na publicação. Estes, entretanto, tornaram-se numericamente menores na medida em que compartilhamentos e curtidas aumentaram. Os comentários relativos à inauguração da exposição, noticiada em veículo de comunicação de grande circulação na capital, por sua vez, foram mais agressivos.

11 Esse espaço público é famoso tanto pela "função" quanto pela "viração" que acolhe. A primeira refere-se a prática da "aquendação" e/ou "pegação", ou seja, entendido como práticas sexuais; a segunda também pode ser entendida como o exercício da prostituição. Pegação de homens gays e travestis da cidade, também apropriado constituindo um território de prostituição. À noite, a Rua José Bonifácio localizada em um dos entornos do parque é ocupada por michês (garotos de programa), enquanto as travestis se prostituem há algumas décadas no seu interior. Em entrevista para o Jornal do Nuances em 2004 a travesti Rubina confirmou que tanto a prostituição, quanto a pegação existiam nesse local há muitos anos: “[...] tinha putaria na rua José Bonifácio (que depois virou ponto noturno para michês, como é até hoje), na avenida João Pessoa; e claro no Parque da Redenção (onde, segundo ela e a gente não duvida sempre teve pegação forte). A Redenção tinha mais matinhos e era um ambiente perfeito para as aquendações" (BOER, 2003; Jornal do Nuances, 2004, p. 6-7). 


\section{A Seleção de Acervo e a Definição dos Eixos Temáticos para a Exposição de Curta Duração}

Porto Alegre não foge à regra quando se trata da ausência de coleções relativas à memória e história LGBTT em museus. ${ }^{12}$ Entretanto, essa lacuna é radicalmente oposta ao numeroso acervo sob guarda de particulares, especialmente no caso de fotografias. Ao contrário do que o senso comum poderia inferir, o acervo LGBTT existe, é rico e diversificado. Nesse sentido, foi preciosa a rede de relações e indicações que permitiram acessar protagonistas LGBTTs, pessoas com experiências e trajetórias fundamentais para a narrativa da exposição.

As coleções de imagens do acervo pessoal de Marcelly Malta - Presidenta da associação Igualdade, e de Maythe (Figura 2) - militante do Nuances, por exemplo, trazem uma retrospectiva riquíssima dos lugares, das personalidades, da moda e dos "babados" da vida das travestis e mulheres transexuais ao longo do tempo em Porto Alegre. Além das fotos, jornais, convites, cartazes e folders de festas, atos políticos e campanhas, especialmente do Nuances e da LBL-RS, constituem um acervo ainda inexplorado com imenso potencial para criação de propostas inovadoras.

Figura 2 - Em destaque Maythe durante a abertura da exposição. Acervo Museu de Porto Alegre Joaquim Felizardo (2016).

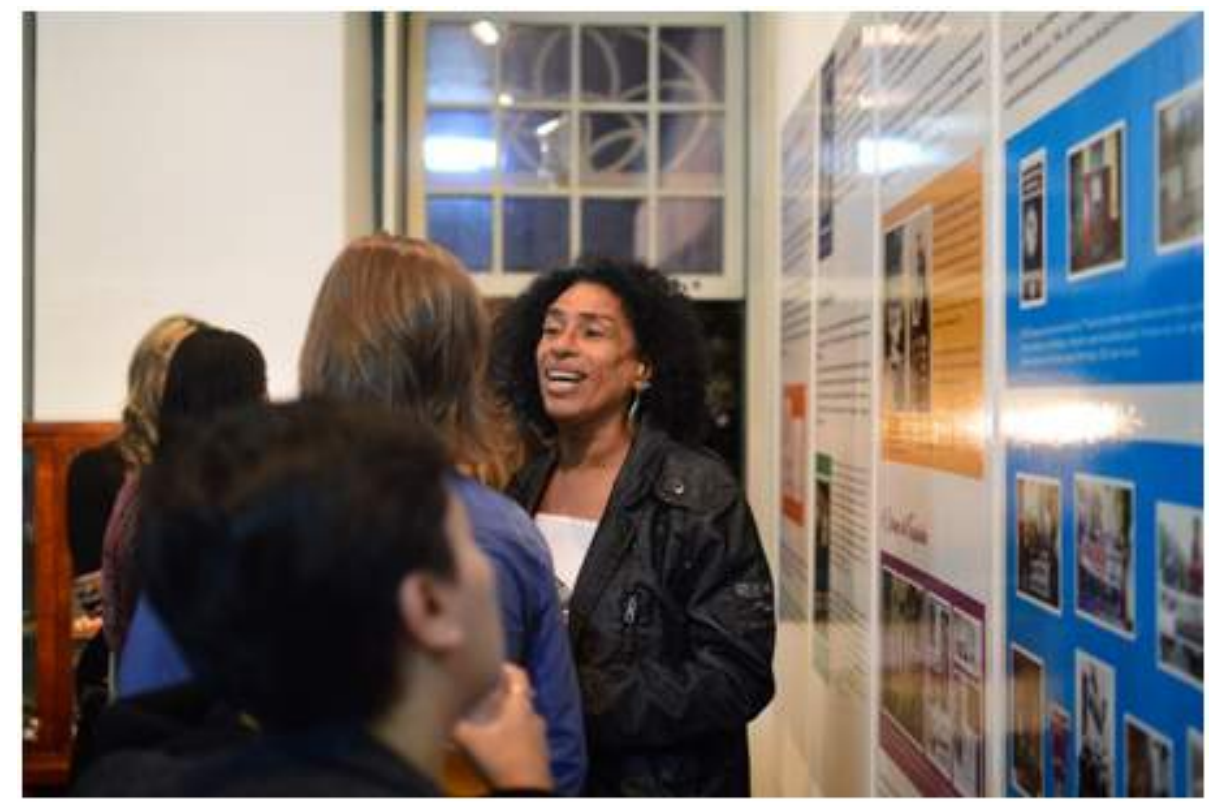

12 Exceção deve ser feita ao Memorial do Rio Grande do Sul, instituição que recebeu uma doação expressiva de documentos do grupo Nuances, após a exposição realizada em comemoração aos 22 anos do grupo, no ano de 2014, que contou parte de sua história. Saiba mais sobre a exposição em:<http://www.sul21.com.br/jornal/22-anos-de-nuances-exposicaoretrata-historia-de-luta-por-direitos-grupo-LGBTT/>. Acesso: 19 fev. 2017.

Fabiano Barnart, Leticia Bauer 
Por outro lado, enfrentamos certa dificuldade em localizar objetos tridimensionais. Como exemplo disso é possível citar a ausência de peças de indumentária, item importante retratado nas fotos e recorrentemente citado em conversas informais, uma vez que a maioria das entrevistadas alegou ter se desfeito dos vestidos e adereços mais antigos. Na exposição, contamos com uma "montaria"13 completa da Drag Queen Vanessa Thundercat" ${ }^{14}$ (Figura 3) composta por sandálias, vestido longo de paetês e peruca. No que se refere ao Museu de Porto Alegre Joaquim Felizardo, foi acessado o acervo fotográfico e tridimensional, em especial a coleção sobre Carnaval, festa relevante para a narrativa da exposição, como se verá a seguir. Sobre o mesmo tema, foram pesquisados jornais no acervo do Museu de Comunicação Hipólito José da Costa.

Figura 3 - Montaria da Drag Queen Vanessa Thundercat, cedida para exposição. Ao fundo visitantes observando o acervo fotográfico. Foto: Arthur Becker/Acervo Museu de Porto Alegre Joaquim Felizardo (2016).

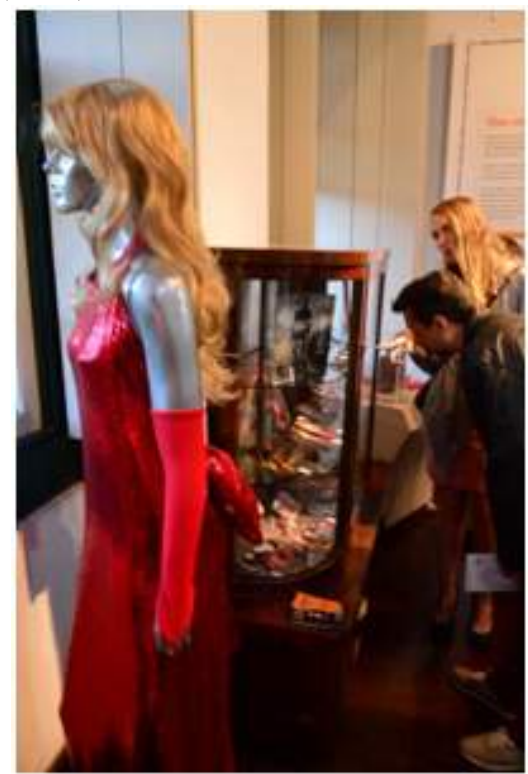

Muitas foram as propostas referentes aos possíveis eixos temáticos que poderiam compor a exposição. Para além da limitação de espaço, fator que evidentemente influenciou a museografia, foi necessário atentar às especificidades do acervo. Após diferentes arranjos e muitas ideias, foram dois os eixos definidos para estruturar a exposição de curta duração: de uma parte, a mostra explorou a trajetória de pessoas e organizações que protagonizaram a luta pela visibilidade e pelo direito à diversidade em Porto Alegre, tendo como ponto de partida o entendimento de que a defesa dos direitos humanos da população LGBTT é condição fundamental para a cidadania plena. De outra, cartografou a cidade sob esta perspectiva, identificando espaços públicos e privados de sociabilidade fundamentais para a construção dessa narrativa. A seguir, passamos a um breve relato sobre a exposição de curta duração, elencando alguns dos recursos espaciais e narrativos utilizados pela equipe.

13 Termo contemporâneo utilizado para definir o figurino, ou seja, o conjunto de itens que compõem vestimentas e adereços de uma Drag Queen.

14 Personagem criada por Auri Fontes. 


\section{Percorrendo a Exposição: História e Memória LGBTT em 'Uma cidade pelas margens'}

Para ritualizar de maneira lúdica o acesso à sala da exposição, optamos por colocar uma cortina de tecido formada pelas cores do arco-íris (Figura 4). Símbolo do movimento LGBTT, o arco-íris esteve presente ao longo da exposição, seja formalizando a entrada da sala, seja como bandeira pendurada na parede, ao lado da Bandeira do Orgulho Trans, ou como recurso gráfico para a linha de tempo.

Figura 4 - Marcelly Malta atravessando a "cortina da diversidade" durante a inauguração da exposição, em novembro de 2016. Foto: Arthur Becker/Acervo Museu de Porto Alegre Joaquim Felizardo (2016).

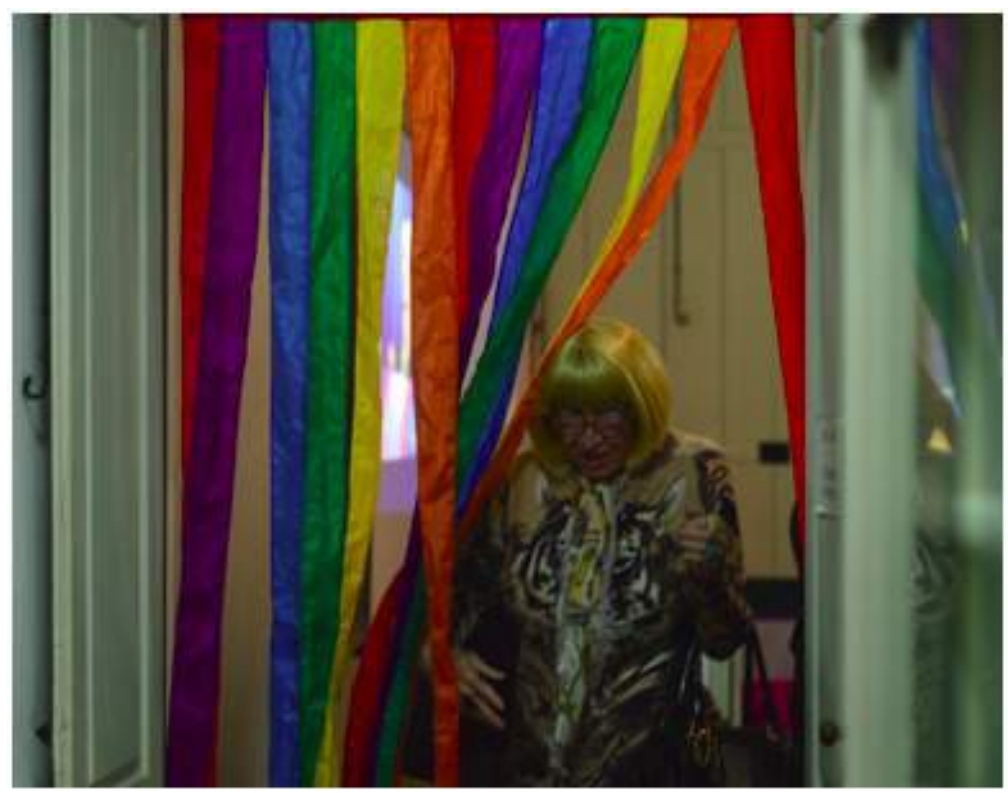

$\mathrm{Na}$ entrada da sala, atravessada a "cortina da diversidade", posicionamos o Biscoito Sexual ${ }^{15}$ (Figura 5), dispositivo pedagógico-dialógico idealizado como disparador para as discussões sobre as categorias de identidade de gênero, orientação sexual, sexo biológico e expressões de gênero, com potencial para ser utilizado no combate ao preconceito e a discriminação. Essa ferramenta foi construída a partir de uma perspectiva espectral, desconstruindo a lógica hegemônica do binarismo de gênero (macho/fêmea; homem/mulher; masculino/feminino) imposta pela sociedade heterossexista. A necessidade de escolher um dispositivo pedagógico de fácil entendimento surgiu ao longo do planejamento da exposição para atender uma demanda do Setor Educativo do Museu, uma vez que a maioria do público visitante é formado por estudantes de escolas públicas e privadas. O Biscoito Sexual revelou-se um excelente instrumento para iniciar o diálogo na mediação, mostrando-se um recurso importante também para os adultos.

15 O "Biscoito Sexual" teve como fonte um recurso desenvolvido pelo site It's Pronounced Metrosexual. Sua forma remete a um biscoito de mel, daí sua denominação.Disponível em: $<$ http://itspronouncedmetrosexual.com/2011/11/breaking-through-the-binary-genderexplained-using-continuums/\#sthash.GmJF8g45.dpbs>. Acesso: 19 fev. 2017. 
Figura 5 - Em destaque uma visitante da exposição fazendo um registro fotográfico do Biscoito Sexual, durante a abertura/inauguração. Foto: Acervo Museu de Porto Alegre Joaquim Felizardo (2016).

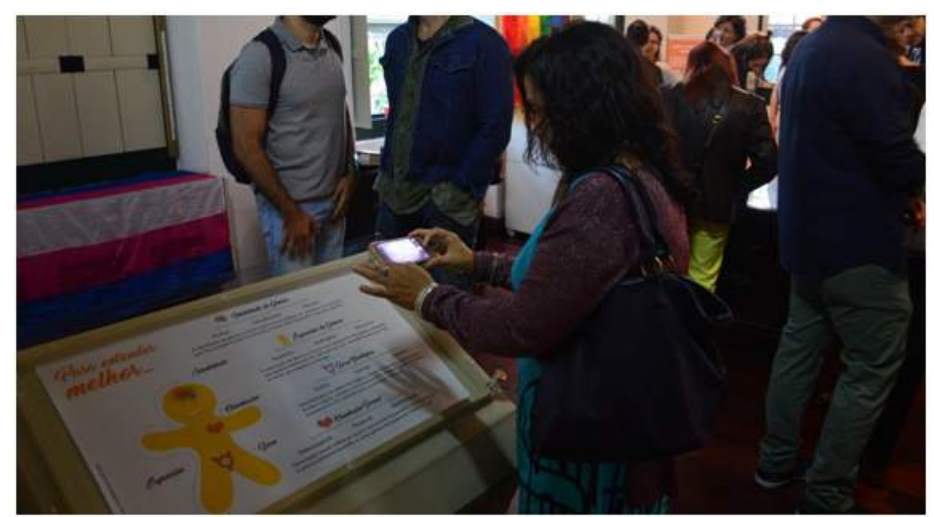

Partimos do entendimento de que gênero e sexualidades são assuntos fundamentais para formação cidadã e sabemos que existe uma dificuldade em abordar essas questões no espaço escolar, em especial depois da retirada dos termos de gênero e sexualidades dos Planos de Educação em diversas cidades e estados brasileiros. ${ }^{16}$ Anualmente, milhões de jovens sofrem cotidianamente as consequências de viver em uma sociedade heterocisnormativa ${ }^{17}$. Esses

16 Em 2014, mobilizações capitaneadas por parlamentares e por grupos conservadores e fundamentalistas, ameaçando a laicidade do Estado,utilizaram-se do falacioso conceito de "ideologia de gênero" para suprimir do Plano Nacional da Educação os termos "igualdade racial, regional, de gênero e orientação sexual". Em 2015, mobilizações análogas avançaram nos estados e municípios. Na Assembleia Legislativa do RS, coalizões conservadoras lograram retirar todas as menções à "identidade de gênero" do Plano Estadual de Educação, apesar da mobilização contrária a esta alteração promovida pela comunidade escolar e organizações de direitos humanos e da população LGBTT. Embora realizada de maneira oficial e legal, a retirada destes termos fere diretamente o princípio fundamental da Constituição Federal relativo à dignidade da pessoa humana, corroborado por resoluções do Conselho Nacional e Estadual de Educação, bem como o objetivo fundamental da República Federativa do Brasil de promover o bem de todos sem preconceitos de origem, raça, sexo, cor, idade e quaisquer outras formas de discriminação. A escola e as políticas de educação devem fomentar a vivência democrática e o aprendizado da cidadania, contribuindo para a consecução dos direitos individuais e coletivos, conforme apregoado na Constituição Federal, que no seu Art. $5^{\circ}$ expressa que todos são iguais perante a lei sem distinção de qualquer natureza. O projeto de lei "Escola sem Partido", ora em tramitação na Assembleia Legislativa, ameaça agravar ainda mais a situação. Diante deste cenário, é urgente que nos mobilizemos pelo debate público que reconheça os direitos sexuais e de gênero enquanto direitos humanos; pela articulação social e política que objetive a reinclusão dos termos retirados dos Planos de Educação em todos os três níveis da federação, com foco no plano do estado do RS; pela afirmação da escola como espaço de construção da cidadania, de promoção da dignidade e de enfrentamento das opressões; pela contraposição a essas e outras investidas, como o projeto de lei "Escola Sem Partido [...]" - texto construído coletivamente por militantes do NUANCES para o projeto submetido ao Edital do Fundo Brasil de Direitos Humanos, em janeiro de 2017 (NUANCES, 2017).

17 Criado na década de 1990, segundo Nardi e Machado (2015), o termo heteronormatividade trata da "[...] função normativa da sexualidade heterossexual, ou seja, à forma como a norma da sexualidade elege a heterossexualidade como padrão, o normal, com base no qual todas as outras expressões da sexualidade são hierarquizadas, julgadas, definidas e esquadrinhadas" (p. 160). Para esses autores, "A hetero[cis]normatividade é a base da violência simbólica, material e física que afeta o amplo espectro das expressões da sexualidade" (NARDI; MACHADO, 2015 , p. 161). Nota-se que esse conceito está relacionado à orientação sexual. A heterocisnormatividade incorpora a noção de cisgeneridade que se refere ao gênero, ou seja, a pessoa cisgênera ou cis seria aquela que se identifica com o gênero que lhe foi atribuído ao nascimento (GUIMARÃES, 2013). Enquanto as pessoas transgêneras ou trans seriam aquelas que não se identificam com o gênero imposto ao nascimento (Ibid.) (BARNART, 2016). 
sujeitos são vítimas do preconceito e discriminação que são materializados através das violências expressas desde os pequenos atos discriminatórios até as violências físicas e psíquicas que podem, em situações extremas, levar à morte (NUANCES, 2016). A violência letal, suicídios ${ }^{18}$ e homicídios, corresponde à resultante mais cruel do preconceito e da discriminação, que podemos evidenciar através da análise dos casos de assassinatos e suicídios na população LGBTT.

Nos estabelecimentos de ensino, a expressão dessas violências resulta na evasão escolar dos grupos populacionais mais vulneráveis. Não raro, as próprias instituições são coniventes com essas violências, seja por meio da omissão ou, até mesmo, sendo polo de sua reprodução (NUANCES, 2016). Levando isso em conta, o projeto Uma Cidade pelas Margens também buscou converter-se em uma iniciativa para atuar na redução do impacto negativo que a mudança nos planos de educação está causando à sociedade, fortalecendo a juventude que sofre preconceito e discriminação, contribuindo para redução do bullying, da violência e da discriminação institucional e, consequentemente, com potencial para contribuir no combate a evasão das instituições de ensino. A equipe de mediação, formada pelo Setor Educativo do Museu e por estudantes do Bacharelado em Museologia da UFRGS ${ }^{19}$, recebeu grupos escolares e visitantes espontâneos, mantendo um diário de campo onde foram registradas observações relativas ao dia a dia da visitação.

Um painel adesivado com cerca de $2,00 \mathrm{~m} \times 3,00 \mathrm{~m}$ recebeu a maior parte do material digitalizado ao longo da pesquisa. Margeado pela própria definição de margem dada pelo dicionário, o painel buscou reunir registros de pessoas visando o debate acerca das diferentes expressões e identidades de gênero ao longo do tempo na cidade de Porto Alegre (Figura 6).

Figura 6 - Plano geral da exposição. Foto: Guilherme Lund/Acervo Museu de Porto Alegre Joaquim Felizardo (2016).

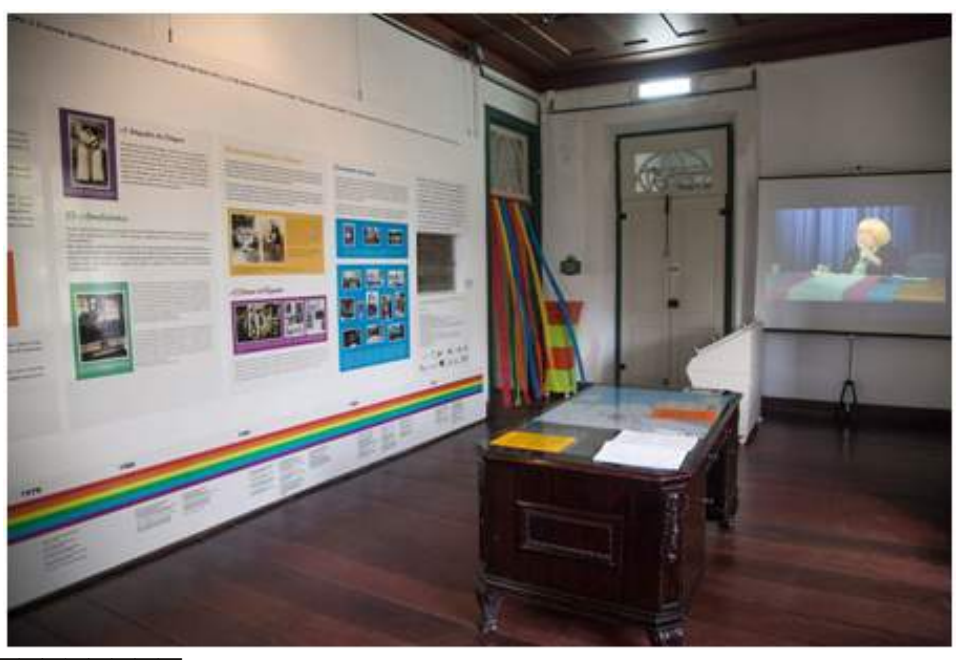

18 Entendido como uma violência letal autoinfringida, que também pode ser relacionado ao preconceito e discriminação, conforme visto anteriormente.

19 Essa parceria foi viabilizada pelo Projeto de Extensão Universitária "Uma Cidade pelas Margens" ( $\left.n^{\circ} 32818\right)$, coordenado pela professora Marlise Giovanaz e pelo professor Eráclito

Pereira - Departamento de Ciência da Informação / Faculdade de Biblioteconomia e Comunicação da UFRGS. 
$\mathrm{Na}$ parte inferior do painel foram assinalados marcos específicos de conquistas e acontecimentos relevantes para a população LGBTT nas escalas municipal, nacional e também internacional por meio de uma linha do tempo (Figura 6), iniciando na década de 1960 com a Revolta de Stonewall. Como recurso auxiliar, foram elaboradas plaquetas móveis com complementação e aprofundamento das informações da cronologia.

Figura 7 - Painel adesivado com destaque para Linha do Tempo de conquistas e acontecimentos marcantes para população LGBTT. Foto: Arthur Becker/Acervo Museu de Porto Alegre Joaquim Felizardo (2016).

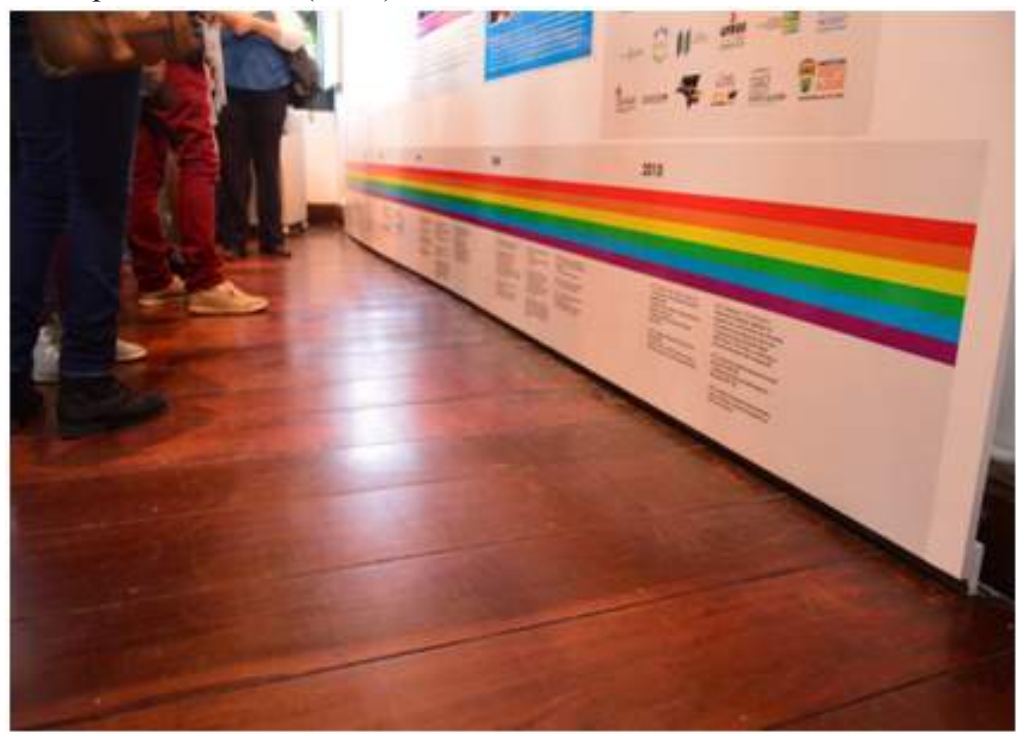

No Brasil, a trajetória dos movimentos sociais LGBTT fortaleceu-se no final da década de 1970. Nesse período, marcado pelo processo de redemocratização do país, surgiram grupos militantes engajados na luta contra o preconceito e em favor da livre orientação sexual. De acordo com o Relatório da Comissão Nacional da Verdade,

[...] a eliminação de direitos democráticos e de liberdades públicas desencadeada pelo golpe de 1964, com a instauração de um regime autoritário e repressor, adiou as possibilidades da constituição de um movimento dessa natureza no Brasil, adiando-se a emergência de atores políticos que pautavam esses temas na cena pública. Paralelamente, a ditadura reforçou o poder da polícia, a censura sobre diversas esferas da vida e as arbitrariedades da repressão estatal, instituindo uma notória permissividade para a prática de graves violações dos direitos humanos de pessoas LGBT (BRASIL, 2014b, p. 300)

Em Porto Alegre, essa trajetória protagonizada por grupos engajados na luta pelos direitos da população LGBTT iniciou em 1991, com a fundação do Movimento Homossexual Gaúcho (MHG), atualmente denominado Nuances Grupo pela Livre Expressão Sexual. Ao longo do tempo, surgiram outras entidades como o Grupo Igualdade (1999), a LBL-RS (2003), a ONG Outra Visão - Grupo LGBTT (1999) e o Grupo Somos - Comunicação, Saúde e 
Sexualidade (2001), entre outros.

A perspectiva da militância foi apresentada na exposição sob o título 'O movimento das margens' e teve como conceito-chave a LGBTfobia, expressão política utilizada para descrever atitudes ou comportamentos que são mobilizados por preconceito às pessoas com orientação sexual e/ou identidades ou expressões de gênero diferentes do modelo heteronormativo. Fotografias de conquistas e manifestações pertencentes aos acervos da Igualdade, da LBL e do Nuances foram apresentadas em contraposição aos registros fotográficos de um cartaz (Figura 8) recolhido pelo Nuances no Parque Farroupilha dias antes da $7^{\text {a }}$ Parada Livre, realizada em 2003, no qual uma arma apontada para o leitor aparece vinculada à frase "Faça o seu dia feliz, acabe com o homossexualismo", além de fotografias de suásticas pichadas em diferentes locais da cidade, em especial na fachada do Vitraux (Figura 9), casa noturna LGBTT que existe desde o início da década de 1980.

Figura 8 - Cartaz incitando ódio e violência contra homossexuais, assinado pela Resistência 88. Foto: Acervo do Nuances.

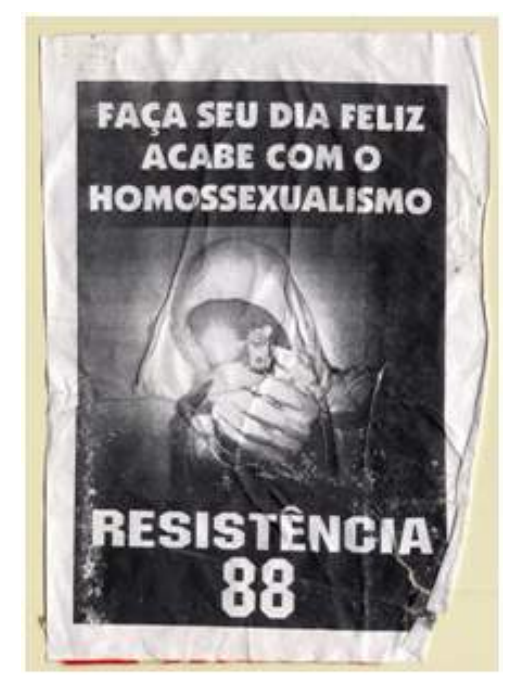

Figura 9 - Suástica pichada na fachada do Vitraux, em Porto Alegre. Foto: Acervo do Nuances.

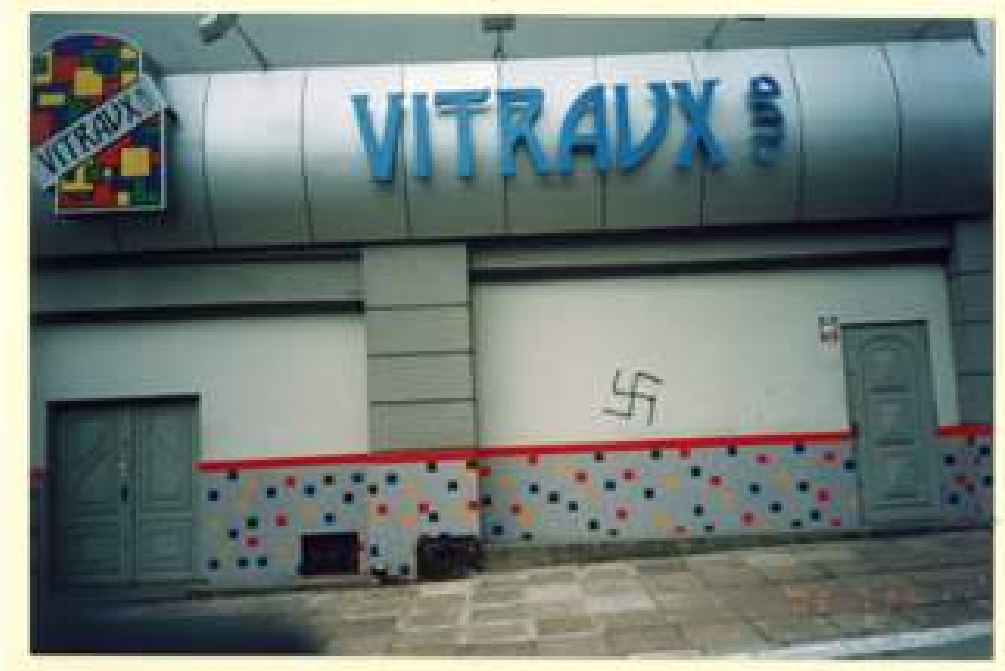

Fabiano Barnart, Leticia Bauer 
Junto a este núcleo também foi plotado o artigo 150 da Lei Orgânica do Município, resultado de uma emenda parlamentar mobilizada pelo Nuances que prevê multa e outras punições a estabelecimentos comerciais que praticarem atos de discriminação, inclusive por orientação sexual.

A exposição também teve o intuito de mostrar ao público que a diversidade de identidades e expressões não é uma realidade recente. Para tanto, recuamos no tempo e apresentamos três momentos diferentes: a fotografia de Virgílio Calegari que há havia mobilizado o público por meio da postagem no Facebook; a peculiar figura do Almofadinha da década de 1920; e as folias de Carnaval entre as décadas de 1930 e 1960, com destaque para a "Cabana do Turquinho". Como bem observou Célio Golin, em texto publicado no jornal eletrônico Sul21, essa perspectiva da exposição "trouxe as experiências vividas por muitas vidas dentro de um espaço urbano que teima em não reconhecer as dimensões desses humanos (...) reconstruindo uma história que precisa ser contada." (GOLIN, 2017).

No caso da fotografia de Calegari, a ausência completa de informações converteu a imagem em enigma. $\mathrm{O}$ retrato posado, à semelhança de tantos outros realizados pelo autor, não possui informações que auxiliem na identificação das mulheres, tampouco seu contexto de produção. Mais do que oferecer uma explicação ao público, a intenção da curadoria foi justamente estimular perguntas: seriam atrizes, amigas, amantes? Independentemente da resposta, a singularidade dessa imagem do século XIX mobilizou o público expectador, invariavelmente provocando um ou outro comentário como "mas já nessa época?".

Avançando no tempo, exploramos a figura do "Almofadinha". Tendo como ponto de partida a pesquisa da historiadora Alice Trusz publicada em uma das edições do Jornal do Nuances, tomamos conhecimento desse tipo social peculiar que foi registrado entre 1910 e 1920 nas revistas Kodak e Mascara, ambas de Porto Alegre. A expressão "Almofadinha" era utilizada de forma pejorativa na imprensa periódica local e definia indivíduos que não gozavam de boa reputação em função de sua aparência física e comportamento. Não foi possível inferir, a partir das revistas, qual a orientação sexual dos "Almofadinhas". De qualquer modo, incluímos a transcrição de trechos das revistas e uma fotografia do acervo do Museu retratando um provável "Almofadinha", buscando provocar a reflexão sobre o quanto eles desafiaram os papéis de gênero vigentes e incomodaram as convenções heteronormativas.

Um terceiro momento explorou o Carnaval entre as décadas de 1930 e 1960. Orientado pela pesquisa da historiadora Íris Germano (1999) ${ }^{20}$, um primeiro recorte tratou da presença de pessoas LGBT durante a festa entre as décadas de 1930 e 1940. Em Porto Alegre, os carnavais de rua deste período foram marcados por bandas e blocos humorísticos que contavam com grande número de homens fantasiados de mulher, uma "inversão" que era permitida durante os dias de folia. Curiosamente, o grito de guerra do carnaval de 1947 era "HOMEM NÃO!". Nessa época do ano, durante a folia, as travestis tinham possibilidade de circular livremente pelas ruas da cidade e locais públicos, misturadas aos foliões homens que se vestiam de mulher, o que no restante do

20 A historiadora também publicou artigos nos jornais do Nuances no 11 (2000) e 31(2004). 
ano não era possível. Segundo a autora, o Carnaval configura uma "fonte para pesquisar a história de segmentos 'invisíveis' na rotina cotidiana da cidade como os homossexuais e [as] travestis" (GERMANO, 2004, p. 12), e foi assim que a equipe de realização da exposição conseguiu compor parte da narrativa apresentada para o público.

Ao longo da pesquisa, uma localidade pareceu incontornável. Trata-se da Cabana do Turquinho, empreendimento itinerante mencionado em diferentes momentos em conversas informais e vivamente retratado na imprensa nas décadas de 1950 e 1960. A Cabana configurou-se em um dos espaços marginais da cidade com todo "glamour e perigo" que lhe eram próprios, sendo representação presente até os dias de hoje no imaginário social daqueles que conheceram ou ouviram falar de sua existência. Na Cabana eram realizados bailes carnavalescos conhecidos pela diversidade de seus participantes, reunindo pessoas de variadas expressões sexuais, identidades de gênero e classes sociais.

Aquilo era uma bagaceira! Mas também era a festa dos excluídos, do pobrerio, dos vileiros, dos negros, dos operários brutalizados, das gentes feias, daqueles que jamais seriam convidados para um baile no Clube do Comércio, no Leopoldina Juvenil e nem mesmo, no Glória tênis Clube. [...] Mas o baile, atraía também, gentes de outras classes sociais em busca do inusitado, do folclórico, dos mitos que envolviam a Cabana. E, mesmo que viessem sob alegação de olhar o fenômeno, não deixavam de aproveitar a grande orgia que ali acontecia. Não foram poucos os respeitáveis senhores que, na 'Cabana', seriam vistos enroscados numa 'bicha' fantasiada de baiana, freneticamente, dançando a 'Jardineira' [...] (PENNA; CARREIRO, s/n apud GERMANO, 2004, p. 12)

Seja devido à repressão policial ou a sua duração temporária (conforme relato de Ângela Maria ${ }^{21}$, a Cabana abria depois das festas natalinas e estendiase até o Carnaval), fato é que a Cabana foi nômade, ocupando espaços variados alugados por seu proprietário. ${ }^{22}$ Qualquer terreno baldio, galpão ou prédio

21 Cantora nas noites de Porto Alegre, assim nomeou-se em homenagem a famosa cantora fluminense Ângela Maria. Essa personagem também tem muitas histórias a serem contadas em outra oportunidade.

22 De acordo com os relatos de frequentadores e frequentadoras do estabelecimento, o Turquinho era um homem de baixa estatura, porém troncudo, que trabalhava com porteiro (e atuava como cafetão) no American Boite, localizado na Avenida Farrapos. Também trabalhou como porteiro e segurança em outros estabelecimentos. Tinha fama de violento e truculento. Circulava nos espaços de sociabilidade das "bichas", na época também conhecidos como "pederastas", e tinha uma boa relação com os policiais. Conhecia os desejos de seus clientes e tinha todas informações sobre a vida noturna da cidade, daí sua fama na noite (GERMANO, 2004, p. 12). De acordo com a entrevista de Rubina para o Jornal do Nuances, "gostava de bichas que se lambia todo" e seria "apaixonado pela Valéria Gaúcha" (Jornal do Nuances, 2004, p. 7). 
abandonado era suficiente para territorializar as "bichices" e "travestilidades" da Cabana, muitas vezes sem grande estrutura: "O chão podia ser de barro, e aí o salto afundava até o calcanhar!", lembrou Rubina, uma das frequentadoras do local (JORNAL DO NUANCES, 2004, p. 6-7). ${ }^{23}$ Esse lugar emblemático (com seus fiéis frequentadores) desterritorializava ${ }^{24}$ e reterritorializava ${ }^{25}$ facilmente. O esforço para compreender essa dinâmica de sociabilidade LGBTT, através dos processos des-reterritorialização será aprofundado em outra oportunidade pelos autores desse texto.

Ao que tudo indica, a Cabana do Turquinho era um dos poucos locais que aceitava a presença de travestis, ocorrendo, inclusive, concursos de beleza e de fantasias de Carnaval, motivo de orgulho para as vencedoras durante o ano inteiro (GERMANO, 2004). Os bailes de Carnaval aconteciam ao som de orquestras musicais, o que seria um "costume da época, um luxo" (JORNAL DO NUANCES, 2004, p. 7).

No centro da sala, um mapa ampliado da cidade (Figura 10) disponibilizou a localização da Cabana do Turquinho e de outros emblemáticos lugares ligados às sociabilidades LGBTT em Porto Alegre desde a década de 1960. Sob o título 'Quando a margem está no centro', esse recurso foi elaborado a partir de uma cartografia social, que teve como suporte a história oral de seus frequentadores, dando a ver uma rede de sociabilidade ora estrategicamente situada fora do alcance de olhares curiosos, ora declaradamente estabelecida e demarcando política e culturalmente o espaço urbano. Junto ao mapa foi disponibilizado um livro de registro como instrumento para que o público visitante registrasse outros locais que não estivessem sinalizados. A experiência foi exitosa e ampliou consideravelmente o repertório de lugares relevantes para a memória LGBTT em Porto Alegre.

Dentro da sala de exposição também foi reservado um espaço para a projeção de vídeos produzidos pelo projeto "História de Vida e Ação Política"26, realizado através do Laboratório de Políticas Públicas e Ações Coletivas em Saúde - LAPPACS - UFRGS. As histórias de vida foram exibidos em looping durante todo o período da mostra. A primeira etapa do projeto aconteceu em 2015 na Escola de Enfermagem da UFRGS e registrou as narrativas de três sujeitos importantes na história do movimento LGBTT do

23 Até onde foi possível averiguar, a Cabana do Turquinho passou por um galpão de madeira, na Avenida João Pessoa esquina com a Venâncio Aires (onde atualmente localiza-se um posto de gasolina); pela Praça da Alfândega, no centro da cidade; pela Rua Voluntários da Pátria, cuja localização exata não foi identificada; pela Rua Ramiro Barcelos. (BOER, 2003; Jornal do Nuances, 2004).

24 "Simplificadamente podemos afirmar que a desterritorialização é o movimento pelo qual se abandona o território, 'é a operação da linha de fuga' e a reterritorialização é o movimento de construção do território (DELEUZE e GUATTARI, 1997, p. 224 apud HAESBAERT, s. d., p. 8).

25 "[...] Deleuze e Guattari afirmam que a desterritorialização relativa diz respeito ao próprio socius. Isto significa dizer que a vida é um constante movimento de desterritorialização e reterritorialização, ou seja, estamos sempre passando de um território para outro, abandonando territórios, fundando novos. A escala espacial e a temporalidade é que são distintas" (HAESBAERT, s.d. p. 8). 
Figura 10 - Mapa Quando a margem está no centro produto da cartografia dos espaços de sociabilidade LGBTT em Porto Alegre, (1960-2016). Foto: Guilherme Lund/Acervo Museu de Porto Alegre Joaquim Felizardo (2016).

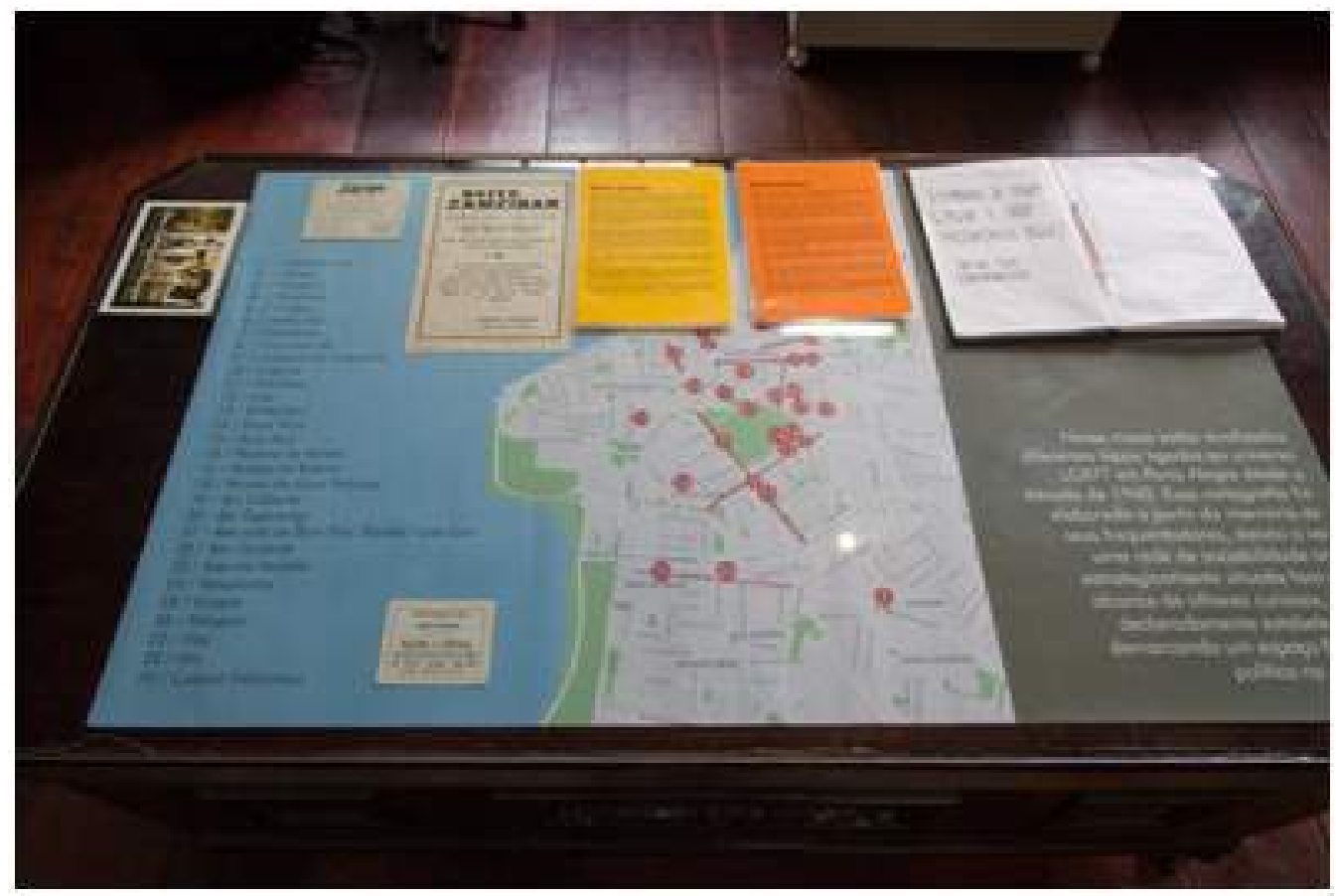

Rio Grande do Sul: Volmar Santos ${ }^{27}$, fundador da Coligay, primeira torcida de futebol organizada no Brasil composta apenas por homossexuais fundada na década de 1970; Marcelly Malta ${ }^{28}$, presidenta e fundadora da Igualdade em 1999; Célio Golin ${ }^{29}$, ativista e fundador do primeiro grupo guei do movimento social LGBTT do Estado.

26 "O projeto História de Vida e Ação Política tem como objetivo trazer para o ambiente universitário experiências de vida marcantes na vida política e social brasileira, propiciando momentos de debate e reflexão sobre a relação entre os indivíduos e a sociedade. Este projeto parte da necessidade de colocar em diálogo a produção do conhecimento acadêmico e as experiências de ativistas e militantes de movimentos sociais que tiveram importantes atividades de mobilização social e de organização política no Estado do Rio Grande do Sul. Além de propiciar um espaço formativo privilegiado para os alunos e alunas da universidade, a organização destes depoimentos poderá contribuir para uma compreensão mais contextualizada das ações políticas, pois possibilita a articulação das distintas formas de mobilização social e resistência política. Colocar em diálogo diferentes líderes de distintos grupos políticos tem sido uma prática de reconhecida relevância entre pesquisadores e militantes." Disponível em: <https://www.facebook.com/events/414406285409865>. Acesso: 23 fev. 2017.

27 Vídeo disponível em: <https:/www.youtube.com/watch?v=cJuHfIGkZEU>. Acesso em: 23 de fev. de 2017.

28 Vídeo disponível em: <https://www.youtube.com/watch?v=9g341q0rZO8>. Acesso em: 23 de fev. de 2017.

29 Vídeo disponível em: <https://www.youtube.com/watch?v=gY78u4pLJA8>. Acesso em: 23 de fev. de 2017. 
'Sabia que Estaria Aqui': Relatos sobre os Processos Criativos do Projeto 'Uma

Cidade pelas Margens'

\section{Marcelly Malta, Rubina e Verusca como protagonistas}

Contar a história da bichice em Porto Alegre é como costurar uma colcha de retalhos. São pedaços de alguma época que conseguimos reconstruir, cenários que montamos novamente, vidas que são lembradas através de depoimentos ou notas de jornal, boletins policiais, cartas, documentos que muitas vezes precisam ser "traduzidos" para que seus verdadeiros significados ultrapassem o que aparentam na superfície, por pressão do preconceito. Ligando uma peça com outro remendo, vamos entendendo qual a cara da bixórdia em outras idades. [...] o nuances se travestiu e foi até a casa da Rubina, travesti de 71 anos de idade e que testemunhou com muito suor e cadência a vida da capital gaúcha de 50 até 90. (Jornal do Nuances, 2004, p. 6)

A fotografia utilizada no convite da exposição (Figuras 11 e 12) é de um grupo de travestis na Cabana do Turquinho, acervo do Nuances. Na foto é possível identificar Rubina, uma famosa travesti da época que, vinda do interior, chegou na Porto Alegre de 1953 aos 21 anos.

Figura 11 - Frente do convite da exposição. Arte: Perseu Pereira (2016).

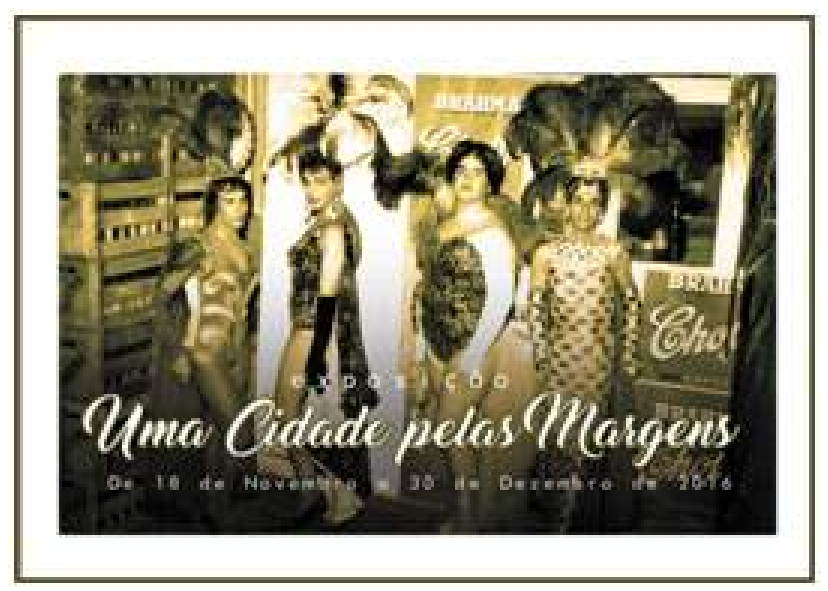

Figura 12 - Verso do convite da exposição. Arte: Perseu Pereira (2016).

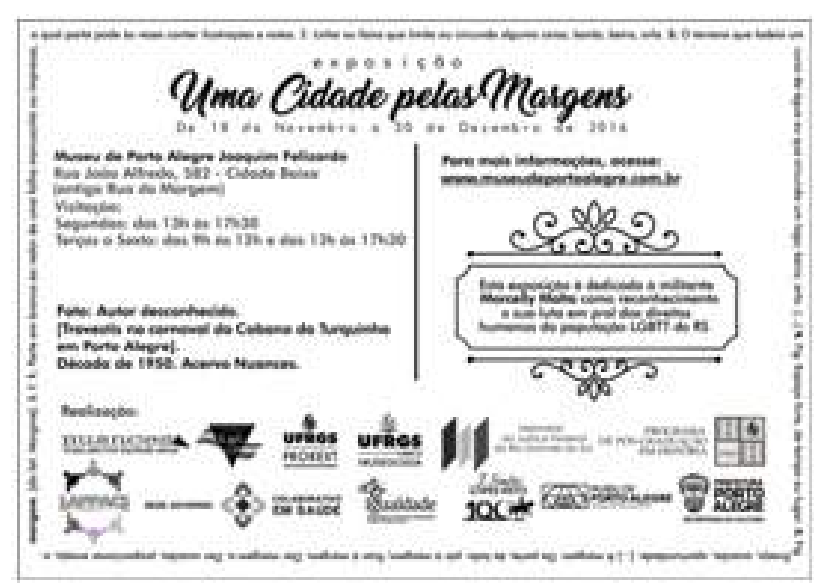

Fabiano Barnart, Leticia Bauer 
O projeto gráfico do banner de divulgação da exposição (Figura 13), colocado na fachada do Museu, também teve como destaque essa personalidade.

Figura 13 - Banner de divulgação da exposição. Arte: Perseu Pereira (2016).

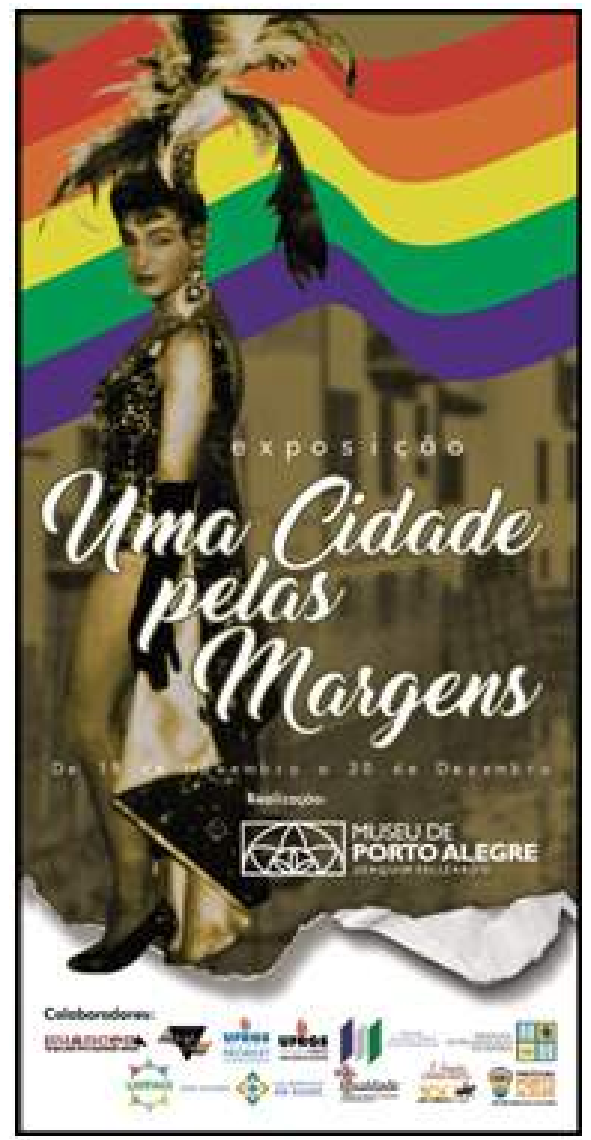

Em 1967, comprou uma casa com dinheiro que recebeu de uma indenização trabalhista, onde começou a alugar os quartos para programas, ficando conhecida como a Pensão da Rubina. De acordo com a entrevista dada por Rubina para o Jornal do Nuances em 2004, esse primeiro estabelecimento funcionou até 1973 e localizava-se na Rua Sarmento Leite esquina com a Avenida João Pessoa, e a segunda pensão funcionou até 1976, na Avenida Osvaldo Aranha. Ambas foram espaços de sociabilidade marcados por diversos escândalos, conforme apontado na entrevista (BOER, 2003; Jornal do Nuances, 2004).

De acordo com sua definição, "fazia a linha vedete", sem "repetir nenhum modelo da "montaria". Segundo afirma, nunca utilizou hormônio ou silicone, ambos inexistentes no Rio Grande do Sul naquela época ${ }^{30}$, dando o "truque" para ficar como queria. Quando chegou a Porto Alegre, a Cabana do Turquinho já "fervia", era "lotada de bichas ricas e pobres". Apesar da má fama considerada um "antro de marginal", nossa protagonista considerava a casa

30 “As Les Girls foram as primeiras travestis com teta de hormônio que passaram em Porto Alegre, no fim dos anos 50. E o silicone só veio a surgir no Rio Grande do Sul no meio da década de 70: até então era tudo truque, com enchimento e cabelo 'joãozinho', peruca era uma lenda e um luxo muito extravagante” (Jornal do Nuances, 2004, p. 7). 
itinerante a melhor coisa que já existiu na cidade: "um luxo" (JORNAL DO NUANCES, 2004, p. 6-7). As sociabilidades marginais da população LGBTT naquela época eram camufladas: só era permitido aos homens vestir-se de mulher no Carnaval e a prática da prostituição acontecia, prioritariamente, dentro dos estabelecimentos privados em função da perseguição da polícia, em especial durante a Ditadura Civil Militar (1964-1985) ${ }^{31}$.

Vale ressaltar que nesse contexto ditatorial, durante a década de 1970, nasceu o Flowers ${ }^{32}$, casa noturna que pertenceu ao empresário Dirnei Messias e se destacou como primeira casa noturna para esse público, incluindo em sua programação shows de travestis entre 1971 e 1975. A boate ainda é lembrada como um espaço de liberdade e segurança, um "porto seguro", como relata uma de suas frequentadoras no documentário "Flores de 70" (Jornal do Nuances, 2004, p. 6-7).

Rubina também foi presença assídua das noites e do Carnaval de Porto Alegre e Pelotas. De acordo com o relatado pelos entrevistadores do Jornal do Nuances, atrás do espelho da sala de visitas, onde foram recebidos, era possível ver uma "pilha de vestidos cheios de brilho", bordados artesanalmente, com franjas, plumas, pedras finas e lantejoulas, parte de uma coleção que, segundo ela, chegou a ter 120 vestidos de gala costurados por uma amiga a partir de seus desenhos.

Por ser uma "bicha" 33 ousada, também sofreu muita discriminação: "Era muito preconceito, cansei de passar na frente de casas de família e baterem as janelas na minha cara", desabafou em 2004. No final de sua vida não se travestia mais e, a partir de 1993, parou de frequentar a noite, pois se sentia deslocada, uma "bicha velha" no meio da juventude (JORNAL DO NUANCES, 2004, p. 7). Na sua história de vida, publicada no livro Construindo a Igualdade: a história da prostituição de travestis em Porto Alegre (BOER, 2003), declarou: "O que eu espero frequentando um bar, uma

31 No período da ditadura civil militar, iniciado com o golpe de 1964, a repressão contra população LGBTT foi sistemática em diversas cidades brasileiras, em especial nos grandes centros urbanos. Desde o início ocorreram violências e violações de direitos na ditadura, porém após dezembro de 1968 houve um "endurecimento do regime com a assinatura do tristemente famoso Ato Institucional no 5 (AI-5)" (FICO, 2015, p. 13). Estudos recentes com base em documentos históricos, notícias de jornal e narrativas de vida comprovam uma intensa operação das polícias civil e militar no sentido de higienizar essas cidades, pois assim como a ameaça comunista, os esquerdistas, democratas liberais, pessoas LGBTT e profissionais do sexo eram vistos como subversivos e, portanto, inimigos do regime militar, o que justificava sua perseguição (FICO, 2015).

32 Espaço de sociabilidade $n^{\circ} 3$ apresentado no mapa da exposição. A discoteca ficava na Praça Jayme Telles e, posteriormente, itinerou para outros locais da cidade - ainda não cartografados. Para saber mais sobre o Flowers sugerimos o documentário "Flores de 70", produzido pelo grupo SOMOS Comunicação, Saúde e Sexualidade, disponível em: $<$ https://www.youtube.com/watch?v=ESvv-VL5_Ks>. Acesso em 22 de fev. de 2017.

33 "Quando se remete às bichas, Rubina refere-se a todas as expressões da sexualidade desviantes da heterossexualidade daquela época, sem a distinção que hoje se faz entre travestis, gueis, transexuais, etc. E ainda antes disso, eram conhecidas no senso comum por 'fronhas' (Jornal do Nuances, 2004). 
boate com 70 anos? Que alguém me ame, que alguém me queira? [...] não tenho mais ilusão de nada. Não tenho ilusão de me vestir [de mulher], pra quê? Ah... pra dizerem: - Olha o puto velho! [...] Tava eu e a Brigite [na noite]... eu disse: Não saio mais! Não tem mais graça!"” (BOER, 2003, p. 38).

Durante a entrevista, Rubem, mostrou-se triste e emocionou-se falando das amigas que perdeu em função da epidemia da AIDS. Para ele, Rubina (Figura 13) existia somente na memória, nas fotos e lembranças. Uma pergunta fica: se vivêssemos em uma sociedade com respeito à diversidade sexual será que

Figura 14 - Foto de Rubina com fantasia de Carnaval em local e data desconhecidas. Foto: Acervo Igualdade.

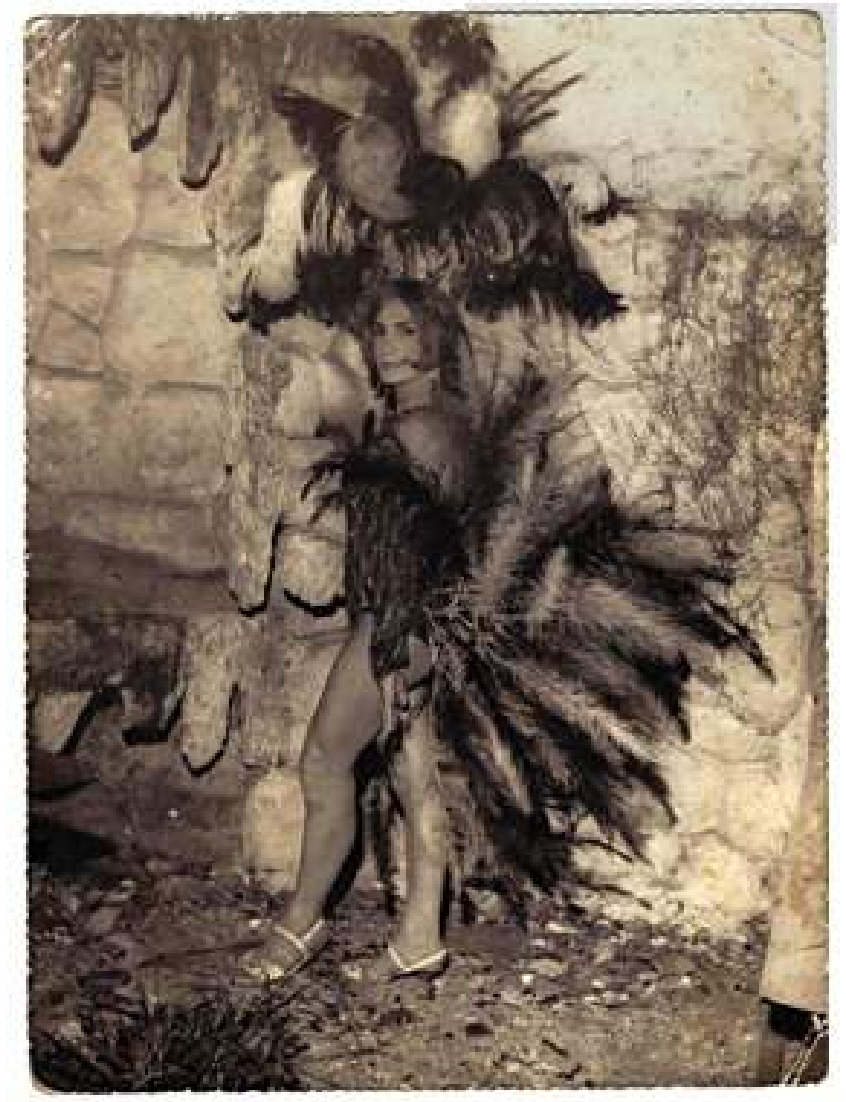

Rubina teria chegado ao fim de sua vida, ao invés de Rubem?

Outra personagem de destaque foi Marcelly Malta, homenageada da exposição de curta duração como reconhecimento a sua luta em prol dos direitos humanos da população LGBTT do RS.

Em sua história de vida ${ }^{34}$, por exemplo, é possível identificar elementos que constituem indícios da relação violenta entre o Estado e grupos de travestis e mulheres transexuais, em especial durante a ditadura civil-militar, baseada no dispositivo legal conhecido popularmente no meio das travestis como a "Lei da Vadiagem". Essa permitia ao poder público, na figura do agente de polícia, estabelecer as sanções do mecanismo disciplinar, legitimado nesse dispositivo

34 A história de vida de Marcelly Malta foi publicada no livro "Construindo Igualdade: a história da prostituição de travestis em Porto Alegre" (BOER, 2013), assim como está disponível no vídeo do projeto "História de Vida e Ação Política", ambos referidos anteriormente. 
legal ou jurídico. Prisões, extorsões, abuso sexual, tortura e morte são situações descritas em diversos momentos do depoimento de Marcelly Malta:

[...] A gente foi presa, né. A gente apanhou tanto, tanto, tanto, que a gente perdeu o sapato. Queria correr e não adiantou. A gente foi presa, a gente não foi pro presídio, mas a gente foi pro Costume. Naquela época a gente ia pro Costume por vadiagem [...] (Depoimento de Marcelly Malta para o projeto História de Vida e Ação Política)

Essa lei, interpretada enquanto um dispositivo legal ou jurídico, a qual Marcelly se refere, foi instituída em 1941, que "considera ociosidade crime e pune 'vadiagem' com prisão [entre 15 (quinze) dias até] de 3 [três] meses", conforme matéria publicada no website do jornal O Globo, em 4 de janeiro de 2014 ${ }^{35}$. Segundo a Lei de Contravenções Penais, no Capítulo VII - Das Contravenções Relativas à Polícia de Costumes, ainda existe o artigo para punição da "vadiagem", conforme segue: "Art. 59. Entregar-se alguém habitualmente à ociosidade, sendo válido para o trabalho, sem ter renda que lhe assegure meios bastantes de subsistência, ou prover à própria subsistência mediante ocupação ilícita" (BRASIL, 1941).

Um dos processos que fizeram parte da exposição, empréstimo do Memorial do Tribunal Federal do Rio Grande do Sul, tratava do caso da travesti Verusca, presa em Porto Alegre no ano de 1976. Nesse processo a travesti foi enquadrada nos Artigos 59 (descrito acima) e 60 da Lei de Contravenções Penais. Esse último descrito como "Importunar alguém em lugar público ou acessível ao público, de modo ofensivo ao pudor: pena multa de duzentos mil réis a dois contos de réis (BRASIL, 1941). O "crime" cometido referia-se ao fato de estar travestida, considerada naquela época um "atentado à moralidade", "perversão sexual" e um "transtorno psiquiátrico", conforme descrito no processo. ${ }^{36}$ Além da prostituição, outra atividade remunerada exercida pelas travestis naquela época era a realização de shows nas boates, inclusive em alguns dos espaços de sociabilidade cartografados na exposição. No entanto, essa atividade configurava uma atividade informal, o que permitia seu enquadramento no art. 59 da Lei de Contravenções Penais.

\section{Atividades Paralelas à Exposição}

Além da exposição de curta duração, desenvolvemos uma programação paralela durante o período da mostra, buscando ampliar a discussão sobre os temas abordados. Foram realizadas duas mesas-redondas, sendo a primeira

35 Disponível em: <http://acervo.oglobo.globo.com/em-destaque/lei-de-1941-consideraociosidade-crime-pune-vadiagem-com-prisao-de-3-meses-14738298>. Acesso 8 de abr. de 2016.

36 A prática da prostituição também era altamente repreendida, inclusive estudos relatam a organização de rondas para reprimir a prostituição durante o período da Ditadura, mesmo que não fosse considerada crime. A análise desse e de outros processos da época da Ditadura estão sendo estudados na pesquisa de mestrado do autor principal desse artigo. 
dedicada às Trajetórias e Memórias da Comunidade LGBT (Figura 14). A mesa contou com a participação das historiadoras Liane Susan Muller ${ }^{37}$ e Íris Graciela Germano ${ }^{38}$. Ambas são autoras de trabalhos que foram utilizados com fonte de pesquisa para a exposição e, ao mesmo tempo, militaram no Nuances.

A segunda mesa, estruturada em torno do tema Direito à Saúde e Caminhos Jurídicos para População LGBT (Figura 15) contou com a participação de Paulo Leivas ${ }^{39}$, Procurador Regional da República no Ministério Público Federal e Henrique $\mathrm{Nardi}^{40}$, Coordenador do Núcleo de Pesquisa em

Figura 15 - Folder de divulgação da mesa redonda "Trajetórias e Memórias da Comunidade LGBTT. Arte: Perseu Pereira (2016).

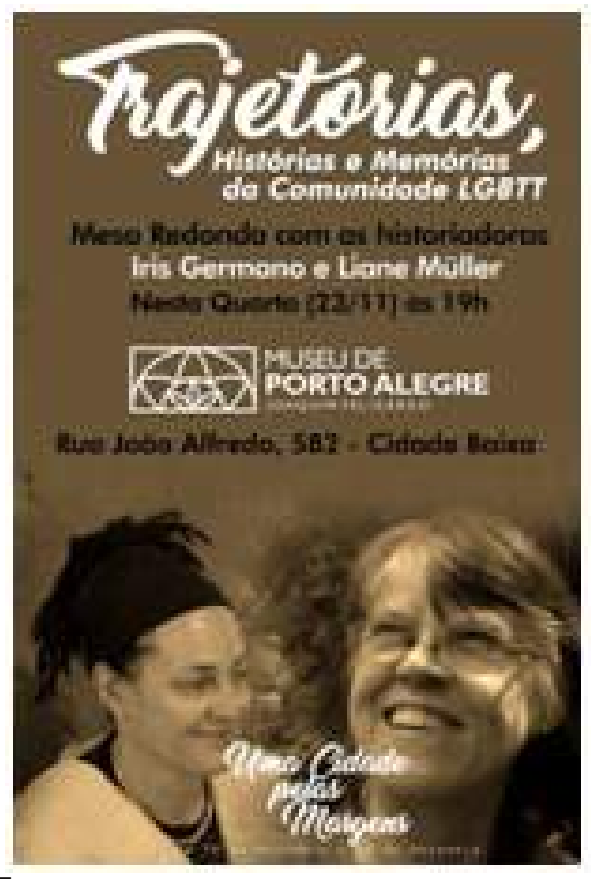

37 Doutoranda em História pela Unisinos. Pós-graduanda em História da África e Cultura Afro-brasileira pela Uniasselvi. Possui bacharelado e licenciatura em História pela Universidade Federal do Rio Grande do Sul (1995) e mestrado em História do Brasil pela Pontifícia Universidade Católica do Rio Grande do Sul (1999).

38 Possui graduação em História pela Universidade Federal do Rio Grande do Sul (1994), especialização em História Social da Cidade pela Unisinos (1998), mestrado em História pela Universidade Federal do Rio Grande do Sul (1999) e atualmente é doutoranda do curso de História da PUCRS (2010).

39 Graduado em Ciências Jurídicas e Sociais pela UFRGS (1993), Mestre em Direito pela UFRGS (2002) e Doutor em Direito pela UFRGS (2009). É Professor do Curso de Mestrado em Direitos Humanos da UNIRITTER/Porto Alegre. É Professor de Ética e Direito UFCSPA. É membro do Ministério Público Federal, em que exerce o cargo de Procurador Regional da República, com atuação na $4^{\mathrm{a}}$ Região. Desenvolve pesquisas sobre direitos humanos, direitos fundamentais, direitos fundamentais sociais, direito à saúde e direitos sexuais. É membro do Núcleo de Apoio Operacional (NAOP) da $4^{\text {a }}$ Região da Procuradoria Federal dos Direitos do Cidadão (PFDC) e do Grupo de Trabalho Educação Indígena.

40 Médico, doutor em sociologia, professor do departamento e do PPG em psicologia social e institucional da UFRGS e do PPG em saúde coletiva da UFRGS. Coordenador do Núcleo de Pesquisa em Sexualidade e Relações de Gênero e do Centro de Referência em Direitos Humanos: Relações de Gênero, Diversidade Sexual e Raça. Diretor do Instituto de Psicologia da UFRGS. 
Figura 16 - Folder de divulgação da mesa redonda "Direito à Saúde e Caminhos Jurídicos para a população LGBTT. Arte: Perseu Pereira (2016).

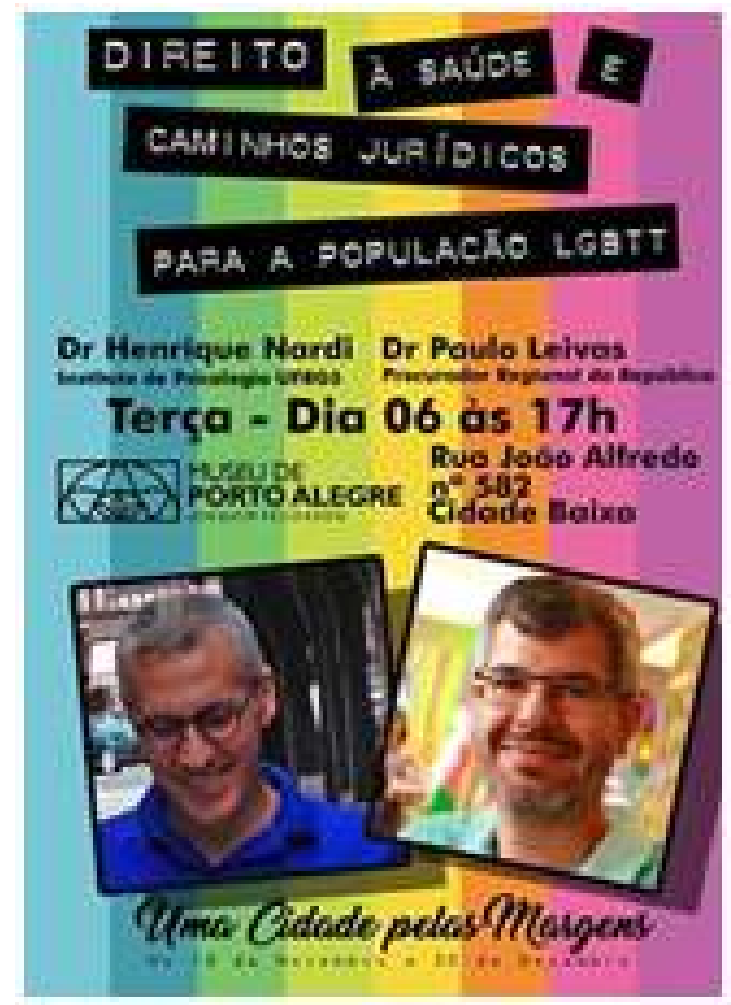

Sexualidade e Relações de Gênero (NUPSEX).

Para finalizar a programação, foi realizado um piquenique cultural temático, em parceria com a equipe de produção do Piquenique Cultural no Museu ${ }^{41}$. Os piqueniques realizados no jardim do Museu chegam a reunir cerca de 2 mil pessoas por evento, sendo que a edição temática contou com exposições das capas dos jornais do Nuances no jardim, intervenções artísticas e apresentação de bandas. A Drag Queen Vanessa Thundercat foi a hostess do evento, pontuado por apresentação de Atena Roveda ${ }^{42}$, Saday Rossini ${ }^{43}$ e León

41 Iniciativa de Ítalo Batistella e Pedro Loss, com produção do Studio Jam e parceria com o coletivo Gastronomia em Movimento.

42 "Mulher transexual, apresenta a arte Queen que revela não somente o lazer da arte, mas a discussão do que é vida humana e os padrões dessa existência. A arte Drag não somente como ostentação do belo e do performático, mas como instrumento de memória e luta de qualquer existência homolesbobitrans humana. Não somente a arte pela arte, mas a arte por essas vidas humanas. Que toda arte Drag carregue a memória de vidas que foram mortas, de vozes não ouvidas, de sorrisos não lembrados. Que a Arte Drag invoque para perto de nós as vidas que um dia se foram" (descrição enviada pela própria artista para divulgação do evento).

43 Transformista da geração da década de 1980 possui o título de Miss Plenitude de 2009 e é frequentadora assídua da Banda da Saldanha. Para saber mais sobre a Banda da Saldanha acesse o site: $<$ http://www.bandasaldanha.com.br/> Acesso em 20 de fev. de 2017.

44 Performer Drag King desde 2015. De maneira simples e resumida, o Drag King é o contrário da Drag Queen, ou seja, uma mulher que performa o gênero masculino, com objetivo de desconstruir a ideia de "machão" através da "montaria" e dublagem. 
Rojas $^{44}$.

\section{Considerações Finais e Novas Questões}

Há história, há memória, há acervo e, principalmente, há demanda pela presença LGBTT em museus, memoriais, arquivos e bibliotecas. Mas não basta falar sobre, é necessário partilhar a fala com os protagonistas dessa e de outras experiências. Um Museu, sozinho, não faz exposição. É necessário e urgente que instituições responsáveis pela guarda, pesquisa e exposição de acervo ampliem seus horizontes e chamem ao diálogo movimentos, militantes e organizações que representem diferentes identidades. Como afirmou o militante Célio Golin:

Ocupar um lugar como o Museu Joaquim José Felizardo, que tem um histórico de reconhecimento por tudo o que representa, também pode ser um dado a se pensar. Uma exposição que pela primeira vez traz para dentro de um espaço como esse a questão das homossexualidades, tem um sentido muito especial, pois aproxima a discussão sobre a ocupação dos espaços públicos pelos sujeitos marginais, os empoderando em vários aspectos, tantos os simbólicos de visibilidade e autoestima, como de apropriação dos espaços da cidade, num sentido pedagógico, questionando o que é realmente público numa cidade. (GOLIN, 2017)

O processo de criação coletiva que resultou no desenvolvimento do projeto 'Uma cidade pelas Margens' foi uma experiência mobilizadora. Permitiu o encontro, o diálogo e a troca, levando ao Museu trajetórias de vida que seguem invisibilizadas dentro e fora das instituições. Como afirmou Célio Golin, em texto sobre o processo de elaboração do projeto, não se tratou somente de "pesquisar e organizar algo a ser apresentado à população, mas estar imerso num processo em que, a cada encontro, as margens vinham à tona".

Brigitte foi ao Museu para se ver. E não só ela, mas tantas outras pessoas LGBTT que foram à exposição atraídas pela possibilidade de ser ver em um espaço público dedicado à memória e à história de Porto Alegre. Queremos acreditar que essa exposição foi transformadora para o público visitante e, esperamos, empoderadora para estudantes LGBTTs constantemente assediados e agredidos no ambiente escolar.

Movimento das margens, movimento no tempo, movimento no espaço urbano:

Há países sem lugar e histórias sem cronologia; cidades, planetas, continentes, universos, cujos vestígios seria impossível rastrear em qualquer mapa ou qualquer céu, muito simplesmente porque não pertencem a espaço algum. Sem dúvida, essas cidades, esses continentes, esses planetas nasceram, como se costuma dizer, na cabeça dos homens [seres humanos], ou, na verdade, no interstício de 
suas palavras, na espessura de suas narrativas, ou ainda, no lugar sem lugar de seus sonhos, no vazio de seus corações; numa palavras, é o doce gosto das utopias. No entanto, acredito que há - e em toda sociedade - utopias que têm um lugar preciso e real, um lugar que podemos situar no mapa; utopias que têm um tempo determinado, um tempo que podemos fixar e medir conforme o calendário de todos os dias. É bem provável que cada grupo humano, qualquer que seja, demarque, no espaço que ocupa, onde realmente vive, onde trabalha, lugares utópicos, e, no tempo em que se agita, momentos ucrônicos (FOUCAULT, 2013, p. 19)

Cartografar remete ao descobrimento do espaço geográfico simultâneo ao percurso, como acontecia na época das Grandes Navegações, no Início da Idade Moderna, quando o cartógrafo descobria o contorno da terra na medida da trajetória do navio no mar, às margens do continente, representando esse percurso no papel, no processo de criação dos mapas de navegação. Para essa tarefa é necessário perder-se, lançar-se ao desconhecido. Trata-se de um processo de imersão em um novo mundo de descobertas porque, assim, passamos a ter um olhar diferenciado daquilo que - ingenuamente - achávamos que era conhecido.

Depois da experiência de cartografar os espaços de sociabilidade LGBTT, por exemplo, a cidade nunca mais será a mesma. O espaço se transforma na imaginação através de um processo que pode ser entendido como uma desterritorialização por meio do contato com a memória e a história de LGBTT em Porto Alegre, em um empreendimento que possibilitou a reflexão, apropriação e pertencimento em relação ao espaço urbano por todas as pessoas que foram colocadas à margem. Conforme descrito por Rogério Haesbaert e Glauco Bruce (2002) com base nas reflexões de Deleuze e Gattari: "Pensar é desterritorializar" (p. 9)

À margem ainda estamos, no entanto, conseguimos romper com as fronteiras que nos segregavam nos guetos do passado, iniciando um processo de apropriação do espaço urbano, conquistando outros territórios. Nesse espaço criaram-se novos territórios, disputados através das lutas e mobilizações da nossa população, daqueles que foram os pioneiros nessas trajetórias, nossas e nossos protagonistas nessa exposição. Por isso, somos gratos. As Paradas do Orgulho LGBTT provaram que existimos e somos muitas/muitos e saímos dos armários para ficar onde desejarmos. Desejo ${ }^{46}$ de ser quem se é, de ser livre, mesmo que impuros aos olhos da moral e dos bons costumes

45 "[...] a desterritorialização do pensamento, tal como a desterritorialização em sentido amplo, é sempre acompanhada por uma reterritorialização: 'a desterritorialização absoluta não existe sem reterritorialização, (1992:131, grifos nossos). Essa reterritorialização é a obra criada, é o novo conceito, é a canção pronta, o quadro finalizado" (HAESBAERT; BRUCE, 2002). 
ainda vigentes. De transitar pelos territórios da cidade sem medo de ser pleno. De ir e vir sem receio, já que todo espaço também nos pertence. Porque não se trata apenas de narrar uma história mas de romper normas para despertar sonhos, de se sentir pertencente ao mesmo espaço que deveria ser de todas e todos por direito. Um espaço para toda diversidade. Resistir, (re)existir e (re)conquistar territórios: a cidade também é nossa e ninguém tem o direito de negar ou esconder essa história, temos o direito à cidade e à vida! (BARNART, 2017)

Conforme depoimento do autor do artigo durante o processo de montagem da exposição. Esse processo criativo trouxe à tona memórias de muitos sujeitos, lembranças esquecidas e perdidas pelo tempo que foram ativadas por meio dos encontros, das imagens, dos objetos e das formas inscritas no papel e imagens projetadas na tela. Perdidas no tempo, agora localizadas na nossa lembrança e inscritas no mapa criado a partir das nossas cartografias. Assim como as histórias de vida emprestadas por nossas protagonistas, que sentiram no corpo toda a dor e a delícia de ser quem se é. As marcas foram inscritas nos corpos e essas lembranças compartilhadas e marcadas nas nossas memórias. É inegável que experienciar esse processo deixou marcas nas pessoas que participaram do projeto e, esperamos, no público visitante. Como o cartógrafo que desenha o mapa e mantém as paisagens em sua memória, as descobertas pertencem às pessoas que viveram os encontros proporcionados por essa iniciativa, seja elaborando a exposição, seja conhecendo parte dessa história.

\section{Referências}

AMARAL, Flávio. Os quatro caminhos para o lete: o mergulho de objetos, coleções e acervos LGBTTQ na desmemória. Anais do II Seminário Internacional Museu, memória e ativismo. Goiânia, GO, 2014, p. 237 - 249.

BARNART, Fabiano. Assassinatos Pautados em Gênero: um interstício sobre a violência letal contra travestis, transexuais e homossexuais no Rio Grande do Sul. Trabalho de conclusão do curso de Bacharelado em Saúde Coletiva. Porto Alegre: UFRGS, 2014. 81 p.

BARNART, Fabiano. Análise Territorial da prostituição de mulheres travestis e transexuais na cidade de Porto Alegre. Orientação: Dra. Cláudia Luísa Zeferino Pires. Projeto de Qualificação de Mestrado. Qualificado em junho de 2016. Programa de Pós-Graduação em Geografia - Linha de Pesquisa em Análise Territorial. UFRGS, 2016. 64 p.

46 "Através de Deleuze e Guattari é possível 'fazer a leitura do social desde o desejo, fazer a passagem do desejo ao político, nos quadros dos modos de subjetivação' (GUATTARI e ROLNIK, 1986, p. 3-16 [...]Nunca desejamos só uma coisa, desejamos sempre um conjunto de coisas. [...]Nessa concepção, o desejo cria territórios, pois ele faz uma série de agenciamentos" (HAESBAERT; BRUCE, 2002).

Fabiano Barnart, Leticia Bauer 
'Sabia que Estaria Aqui': Relatos sobre os Processos Criativos do Projeto 'Uma

Cidade pelas Margens'

BAPTISTA, Jean; BOITA, Tony. Protagonismo LGBT e museologia social: uma abordagem afirmativa aplicada à identidade de gênero. Cadernos do CEOM Centro de Memória do Oeste de Santa Catarina. Chapecó, Ano 27, n. 41, dez. 2014.

BRASIL. Planejando a Próxima Década - Conhecendo as 20 metas do Plano Nacional de Educação. Presidência da República. Ministério da Educação/Secretaria de Articulação com os Sistemas de Ensino (MEC/SASE), 2014.

BRASIL. Ditadura e Homossexualidades. Comissão Nacional da Verdade Relatório - Volume II - Textos Temáticos. Brasília: CNV, 2014b. p. 289-301.

FICO, Carlos. Prefácio. In: GREEN, James N., QUINALHA, Renan (Orgs.). Ditadura e Homossexualidades: repressão, resistência e a busca da verdade. São Carlos: EdUFSCar, 2015, p. 13-16.

FOUCAULT, Michel. O corpo utópico, as heterotopias. São Paulo: n - 1 Edições, 2013.

GERMANO, Íris Graciela. Rio Grande do Sul, Brasil e Etiópia: negros e o carnaval de Porto Alegre nas décadas de 1930 e 40. 1999. Dissertação (Mestrado em História) - Universidade Federal do Rio Grande do Sul, Porto Alegre.

GERMANO, Íris Graciela. Homem, não! O Carnaval de rua em Porto Alegre nos anos 30 e 40. Jornal do Nuances - Grupo pela Livre Expressão Sexual, n. 11, n. $2,2000$.

GERMANO, Íris Graciela. A Cabana do Turquinho. Jornal do Nuances Grupo pela Livre Expressão Sexual, n. 31, v. 5, 2004.

GOLIN, Célio. Da Patologia à Cidadania. In: NARDI, H. C.; SILVEIRA, R. S.; MACHADO, P. S. (Org.). Diversidade Sexual, Relações de Gênero e Políticas Públicas. Porto Alegre: Sulina, 2013, p. 73 - 86.

GOLIN, Célio. Uma Cidade pelas Margens: quando uma exposição não é só uma exposição. Jornal eletrônico Sul21. 2017. Disponível em: $<$ http://www.sul21.com.br/jornal/umacidadepelasmargensquandoumaexposica onaoesoumaexposicaoporceliogolin/>. Acesso em $28 \mathrm{de} \mathrm{fev.} \mathrm{de} 2017$.

GUIMARÃES, Beatriz. Cissexual, cisgênero e cissexismo: um glossário básico. Feminismo Trans - $\mathrm{O}$ virtual é poético. Disponível em: $<$ https:/feminismotrans.wordpress.com/2013/03/15/cissexual-cisgenero-ecissexismo-um-glossario-basico/> . Acesso: 12 de abr. de 2016.

HAESBAERT, Rogério; BRUCE, Glauco. A Desterritorialização na Obra de Deleuze e Guattari. GEOgraphia, v. 4, n. 7, p. 1 - 15, 2002.

MUller, Liane Susan. Sinais de Comunicação no Planeta "Noite". 
Trabalho apresentado para disciplina de Antropologia I - Professora Cornélia Eckert. Instituto de Filosofia e Ciências Humanas - Universidade Federal do Rio Grande do Sul. 1992. 70 p.

NARDI, Henrique; MACHADO, Paula Sandrine. Heteronormatividade. In: FLEURYTEIXEIRA, Elizabeth; MENEGHEL, Stela Nazareth (Org.). Dicionário Feminino da Infâmia: acolhimento e diagnóstico de mulheres em situação de violência. Rio de Janeiro: Editora: FIOCRUZ, 2015. 422 p.

NOGUEIRA, Sayonara Naider Bonfin.; AQUINO, Tathiane Araújo.; CABRAL, Euclides Afonso. Dossiê: A Geografia dos Corpos das Pessoas Trans. Sayonara Nogueira e Rede Trans Brasil. Brasil, 2017. Disponível em: $<$ redetransbrasil.org $>$. Acesso 1 de mar. De 2017.

PINTO, Renato. Museus e diversidade sexual: reflexões sobre mostras LGBT e Queer. Arqueologia pública, n. 5, p. 44 - 55, 2012.

REIS, Bruno P. W. Arena Política. Blog Sociologia Política. 2013. Disponível em: <http://adrianocodato.blogspot.com.br/2013/03/arena-politica-bruno-p-wreis.html>. Acesso em 1 de mar. de 2017.

RIOS, Roger Raupp. Respeito x Injúria - o caso dos cartazes violentos em Porto Alegre na $7^{\mathrm{a}}$ Parada Livre. Jornal do Nuances - Grupo pela Livre Expressão Sexual. No24/Ano 4. Porto Alegre, 2003.

RIOS, Roger Raupp. O conceito de homofobia na perspectiva dos direitos Humanos e no contexto dos estudos sobre preconceito e discriminação. In: POCAHY, F. (Org.). Rompendo o Silêncio: homofobia e heterossexismo na sociedade contemporânea: políticas, teoria e atuação. Porto Alegre: Nuances, 2007, p. 27 - 48. 